\title{
O direito à comunicação como princípio fundamental: internet e participação no contexto da sociedade em rede e políticas públicas de acesso à internet no Brasil
}

The Right to Communicate as a Fundamental Principle: Internet and Participation in the Context of the Network Society, and the Public Policies for Internet Access in Brazil

Submetido(submitted): 21 de novembro de 2010

Parecer(revised): 8 de dezembro de 2010

Pedro Augusto Maia Felizola*

Aceito(accepted): 9 de dezembro de 2010

Resumo

O presente trabalho tem por finalidade contribuir para a compreensão do direito à comunicação como direito fundamental e identificar o papel da internet como instrumento tecnológico e suporte material para o seu exercício, a fim de se possibilitar a participação do indivíduo na realidade global da sociedade em rede. Assim, busca-se responder aos seguintes questionamentos: é possível afirmar que o acesso à internet é meio indispensável para a concretização do direito fundamental à comunicação? Se sim, qual é a realidade brasileira quanto à implementação de políticas públicas para difundir o acesso à internet? Os passos percorridos para aclarar tais dúvidas iniciam-se com considerações a respeito do direito à comunicação como princípio fundamental no contexto da sociedade em rede, a partir da indentificação dos critérios para a caracterização de um direito fundamental. Após breves comentários sobre a previsão constitucional acerca do direito à comunicação, discute-se a sociedade em rede como escopo para o reconhecimento do papel indispensável hoje exercido pela internet. Finalmente, foram selecionadas e analisadas políticas públicas do Estado brasileiro para a ampliação do acesso à banda larga no país, a fim de demonstrar, à luz de todo o trabalho, que: o acesso à internet deve ser reconhecido como fundamental; e o Brasil deve valorizar a capacitação e habilitação das pessoas, permitindo-lhes utilizar plena e eficazmente os recursos de comunicação que lhes são ofertados, em face do reconhecimento de tal direito.

\section{Abstract}

This article addresses the relationship between the right to communicate and Internet access. The latter is portrayed as a technological tool for the effectiveness of the right to communicate, making it possible for individuals to participate in the network society. Therefore, it intends to answer the following questions: is it correct to state that Internet access is an indispensable way to guarantee the right to communicate? If so, what is the Brazilian situation concerning to the establishment

\footnotetext{
*Advogado da Trench, Rossi e Watanabe Advogados, associado a Baker \& Mackenzie International, Swiss Verein. Bacharel em Direito pela Universidade de Brasília (UnB). Pesquisador do Grupo de Estudos em Direito das Telecomunicações da UnB.
} 
of public policies to expand Internet access? The steps taken in order to clarify those questions start with a few notes regarding the relevance of the right to communicate in the context of the network society, in accordance with the criteria used to define a fundamental right. After brief comments on the constitutional provisions concerning the right to communicate, the network society is discussed amidst the recognition of the essential role played today by the Internet. Finally, the study analyzes some of the Brazilian public policies for expanding broadband access countrywide, in order to demonstrate, in view of the entire article, that: Internet access should be recognized as fundamental, and Brazil should enhance capacity building and empowerment of people, allowing them full and effective use of communication resources, as a consequence of the enforcement of the right to communicate.

Palavras-chave: direito à comunicação; direitos fundamentais; internet; sociedade em rede; banda larga.

Keywords: right to communicate; fundamental rights; Internet; network society; broadband.

\section{Introdução}

O presente estudo tem por objeto a compreensão da relevância do direito à comunicação no contexto da sociedade em rede e das consequências de seu exercício para a efetivação da participação, notadamente no que diz respeito ao papel exercido pela internet nesse processo.

As transformações pelas quais passa a sociedade são muito mais profundas do que parecem demonstrar as análises que se prendem apenas ao encurtamento das distâncias provocado pela globalização e pela evolução das (tele)comunicações. Trata-se do surgimento de um novo paradigma, um novo sistema, com todas as possibilidades e consequências a ele inerentes.

Tem-se ainda um quadro de desafios e lutas que emergem dessas transformações, sobretudo em face das desigualdades que parecem acentuarse na medida em que poucos têm acesso às novas tecnologias, os quais tendem a se desligar ainda mais daqueles a quem esse acesso é vetado ou impossibilitado. Quanto a este ponto, merece referência, desde já, a exposição do professor Cançado Trindade:

A complexidade dos desafios com que se defronta o mundo de hoje não o torna necessariamente pior do que o de ontem. Com o avanço dos meios de comunicação, jamais houve tanto intercâmbio internacional e tantas oportunidades de aproximação entre os povos como atualmente, favorecendo como nunca o discernimento e a empatia. Vivemos hoje em um mundo inegavelmente mais transparente. No entanto, a despeito da 
revolução dos meios de comunicação, os seres humanos parecem mais isolados e solitários do que nunca, persistindo o risco da massificação e a consequente perda de valores. Tampouco 0 avanço das comunicações pode prescindir da capacidade de discernimento e do espírito de solidariedade humana. ${ }^{1}$

Destaque-se que se pretende caracterizar o direito à comunicação como direito fundamental, a partir de uma leitura constitucional fundada na abertura do catálogo de direitos fundamentais e na necessidade de sua constante atualização, em face das transformações conjunturais, sejam elas econômicas, sociais, políticas ou de qualquer outra ordem.

Tal é o quadro que se verifica ao se analisar a chamada sociedade em rede, de que se ocupa notadamente o professor Manuel Castells. A sociedade em rede representa a atual fase do processo de transição da Era Industrial para a Era Informacional, na qual é possível observar a prevalência das redes como elementos centrais da organização social, tendo a internet como ferramenta tecnológica e suporte material dessa estrutura organizacional complexa e flexível.

Assim, qualificado o direito à comunicação como um direito à informação de mão dupla, por meio do qual o indivíduo obtém acesso a todo tipo de informação e, simultaneamente, expressa suas opiniões e manifesta inquietações, projetos, criações e outras facetas de sua personalidade, tem-se que a internet é o instrumento economicamente viável, socialmente eficaz e tecnologicamente adequado para o exercício desse direito fundamental.

Tanto mais clara se torna tal constatação quando se apresenta a realidade da sociedade em rede, especialmente em países marcados pela desigualdade social, onde se verifica uma tensão entre pobreza digital e transição do industrialismo para o informacionalismo. Tal tensão é, de fato, menos clara em muitos dos países desenvolvidos, que já se encontram na fase do informacionalismo, caracterizada pela penetrabilidade e flexibilidade das redes nos mercados - o surgimento da nova economia -, nas empresas, no

${ }^{1}$ TRINDADE, Antônio Augusto Cançado. Desafios e conquistas do Direito Internacional dos Direitos Humanos no início do Século XXI. In: Desafios do Direito Internacional Contemporâneo. Jornadas de Direito Internacional Público no Itamaraty. Antônio Paulo Cachapuz de Medeiros (org.). Brasília: Fundação Alexandre de Gusmão, 2007. p. 228. 
trabalho, nas relações sociais, na sociedade, enfim. Daí a adequação de analisar o tema a partir do caso brasileiro, como faz o presente trabalho.

O modelo atual de informacionalismo representa, então, um novo princípio de organização da sociedade com o objetivo de se buscar o desenvolvimento a partir do processamento da informação.

Pode-se pensar o direito à comunicação, a partir dessa nova perspectiva, como um elemento central na agenda do século XXI, em consonância com o que expõe o professor Cançado Trindade, no ponto em que este se refere a documentos aprovados em recentes Conferências Mundiais, ao apontar para um novo ethos, indicando justamente que o caminho do desenvolvimento passa pela consideração da relevância da pessoa humana e da concretização de sua dignidade em todas as suas esferas:

Os extensos documentos finais das mencionadas Conferências Mundiais vêm de formar - a partir de um enfoque necessariamente antropocêntrico - a agenda internacional do século XXI, para cuja implementação ainda não se reestruturaram as organizações internacionais. Seu denominador comum tem sido a atenção especial às condições de vida da população (particularmente dos grupos vulneráveis, em necessidade especial de proteção), - conformando o novo ethos da atualidade, - daí resultando o reconhecimento universal da necessidade de situar os seres humanos de modo definitivo no centro de todo processo de desenvolvimento. ${ }^{2}$

Este estudo, portanto, tem por objetivo justamente inserir no debate acerca das políticas públicas brasileiras de acesso à internet elementos constitucionais relativos à caráter fundamental do direito à comunicação, assim como analisar as iniciativas adotadas no Brasil no sentido de transformar a realidade do país, que se encontra ainda em transição para o modelo da sociedade em rede, conquanto a era do informacionalismo já seja vivencida em sua plenitude por muitas nações.

${ }^{2}$ TRINDADE, Antônio Augusto Cançado. Desafios e conquistas do Direito Internacional dos Direitos Humanos no início do Século XXI. In: Desafios do Direito Internacional Contemporâneo. Jornadas de Direito Internacional Público no Itamaraty. Antônio Paulo Cachapuz de Medeiros, organizador. Brasília: Fundação Alexandre de Gusmão, 2007. p. 231.

Revista de Direito, Estado e Telecomunicações, v. 3, n. 1, p. 205-280 (2011)

DOI: https://doi.org/10.26512/1str.v3i1.21671 


\section{Direito à comunicação como direito fundamental}

O capítulo dos direitos fundamentais ocupa lugar de destaque na seara do direito constitucional contemporâneo. As preocupações relativas ao tema ganharam relevância à medida que se observou a afirmação de categorias de direitos e garantias básicos e essenciais dos indivíduos, numa progressão que a doutrina costuma classificar como gerações ou dimensões de direitos fundamentais.

Assim, em face do valor do princípio da dignidade da pessoa humana como elemento central e fundante do Estado Democrático de Direito e do papel assumido pela Constituição como título jurídico supremo deste Estado, unem-se os direitos fundamentais e a força normativa da Constituição ${ }^{3}$ no intuito de resguardar os valores máximos da humanidade, que não podem ficar à mercê dos contextos políticos do Estado. ${ }^{4}$

${ }^{3}$ Para o aprofundamento de tal discussão, ver: HESSE, Konrad. A força normativa da Constituição. Trad. Gilmar Ferreira Mendes. Porto Alegre: Sergio Antonio Fabris Editor, 1991. LASSALLE, Ferdinand. O que é uma constituição? Coleção Rosa dos Ventos, v. 2. Trad. Walter Stönner. Porto Alegre: Editorial Villa Martha Ltda., 1980.

${ }^{4}$ Quanto ao papel da Constituição como elemento de determinação da própria estrutura estatal, cuja relevância não pode ser menosprezada e cuja força espraia-se por todo o ordenamento, conferir trecho de Hans Kelsen: "Através das múltiplas transformações por que passou, a noção de Constituição conservou um núcleo permanente: a ideia de um princípio supremo determinando a ordem estatal inteira e a essência da comunidade constituída por essa ordem. Como quer que se defina a Constituição, ela é sempre o fundamento do Estado, a base da ordem jurídica que se quer apreender. $\mathrm{O}$ que se entende antes de mais nada e desde sempre por Constituição - e, sob esse aspecto, tal noção coincide com a de forma do Estado - é um princípio em que se exprime juridicamente o equilíbrio das forças políticas no momento considerado, é a norma que rege a elaboração das leis, das normas gerais para cuja execução se exerce a atividade dos organismos estatais, dos tribunais e das autoridades administrativas. (...) Ela é a base indispensável das normas jurídicas que regem a conduta recíproca dos membros da coletividade estatal, assim como das que determinam os órgãos necessários para aplicá-las e impô-las, e a maneira como devem proceder, isto é, em suma, o fundamento da ordem estatal." KELSEN, Hans. Jurisdição Constitucional. São Paulo: Martins Fontes, 2003. p. 130-131. 
O presente capítulo buscará compreender qual é o lugar do direito à comunicação na esfera constitucional brasileira, a partir de um entendimento de que o rol de direitos fundamentais previsto no artigo $5^{\circ}$ da Constituição Federal de 1988 é aberto, em face da própria disposição do seu $\S 2^{\circ}$, o qual será objeto de análise mais adiante.

Para tanto, far-se-á necessário encontrar na doutrina constitucional e nas teorias acerca dos direitos fundamentais o arcabouço indispensável à caracterização de um direito fundamental e o modo pelo qual esse direito adquire eficácia.

\section{Classificação de direitos fundamentais quanto à relação entre seus titulares e o Estado}

Uma teoria de direitos fundamentais mostra-se válida apenas no caso de enaltecer o papel de tais garantias para a valorização da pessoa humana, mesmo diante da soberania e do império estatais.

O Estado assume papel de garantidor e provedor dos direitos básicos dos cidadãos, uma vez que foi criado por e para eles. Aliás, essa noção coadunase com a própria origem do constitucionalismo, cujo princípio norteador foi justamente a limitação do poder político, a fim de coibir abusos por parte dos detentores do poder, sujeitando-os às mesmas normas que alcançam os demais, o que indica a necessidade de o Estado - figura na qual se visualiza o poder político - e seus representantes servirem às pessoas, e não controlálas. Daí a lição de Karl Loewenstein:

Limitar o poder político significa limitar os detentores do poder; este é 0 núcleo do que, na história antiga e moderna da política, aparece como 0 constitucionalismo. Um acordo da comunidade sobre uma série de regras fixas, que obrigam tanto aos detentores como aos destinatários do poder, mostrou-se como o melhor meio de dominar e evitar 0 abuso do poder político por parte de seus detentores. ${ }^{5}$

São várias as consequências da compreensão dessa realidade, mas a referência que se quer fazer no momento é em relação às categorias de

${ }^{5}$ LOEWENSTEIN, Karl. Teoría de la Constitución. Trad. Alfredo Gallego Anabitarte. $2^{a}$ ed. Barcelona: Editorial Ariel, 1986. p. 29. Tradução livre.

Revista de Direito, Estado e Telecomunicações, v. 3, n. 1, p. 205-280 (2011)

DOI: https://doi.org/10.26512/1str.v3i1.21671 
direitos fundamentais passíveis de serem extraídas da relação entre cidadãos e Estado, a partir da premissa acima mencionada.

Em geral, podem-se apontar três categorias de direitos fundamentais repita-se, quanto ao critério da relação entre titulares e Estado: direitos de defesa, direitos de prestação e direitos de participação. ${ }^{6}$

Os direitos de defesa visam essencialmente à garantia das liberdades individuais frente ao poder de império do Estado. Os direitos de prestação, por sua vez, têm por finalidade a promoção dos meios necessários à efetiva concretização dessas liberdades. Finalmente, os direitos de participação constituem aqueles "orientados a garantir a participação dos cidadãos na formação da vontade do país, correspondendo ao capítulo da Constituição Federal relativo aos direitos políticos."

Ressalte-se que tais categorias não são estanques, podendo um direito prestacional encontrar origem em um direito de defesa, ou seja, há intensa e necessária interação entre os diversos direitos fundamentais, sendo possível detectar, em vários deles, um caráter ambivalente. ${ }^{8}$

Merece breve referência o ensino do professor Peter Häberle, ao cuidar da realização cooperativa dos direitos fundamentais, a fim de se ilustrar a relevância do tema da efetivação dos direitos fundamentais nas discussões teóricas mais recentes, inclusive no que diz respeito ao Direito Internacional:

A força "motriz" do tipo Estado constitucional não se mostra tão grande em outro âmbito quanto na realização cooperativa dos direitos fundamentais. Seus catálogos dos direitos fundamentais tornam-se exemplo, no âmbito público mundial, de duas maneiras: como esperança dos "cidadãos estatais" de terceiros Estados por direitos fundamentais para si mesmos e como esperança por melhoria, em nível de direitos

${ }^{6}$ Interessante perspectiva sobre a concretização dos direitos fundamentais e a abordagem do Estado Constitucional Cooperativo pode ser encontrada em: HÄBERLE, Peter. Estado Constitucional Cooperativo. Trad. Marcos Augusto Maliska e Elisete Antoniuk. Rio de Janeiro: Renovar, 2007 (especialmente no Capítulo III).

${ }^{7}$ MENDES, Gilmar Ferreira [et al.]. Curso de Direito Constitucional. São Paulo: Saraiva, 2007. p. 255.

${ }^{8}$ MENDES, Gilmar Ferreira. Idem. 
fundamentais, das pessoas como "estrangeiros" nesses Estados. O prestígio do Estado constitucional cresce com sua força para a realização cooperativa dos direitos fundamentais. A estatalidade ganha, aqui, um novo patamar de legitimação. 0 "direito comum de cooperação" recebe dos direitos fundamentais os mais fortes impulsos, integra-os para "tarefas da comunidade" e tem neles um garante confiável. ${ }^{9}$

O trecho demonstra que, de acordo com os pressupostos adotados por Häberle, a cooperação entre os Estados envolve a realização conjunta e coordenada dos direitos fundamentais, funcionando estes inclusive como propulsores da integração entre os países a partir do exemplo dado para o fortalecimento da esperança por melhoria. Os catálogos de direitos fundamentais das diferentes nações, nessa perspectiva, podem e devem dialogar, proporcionando à estatalidade a elevação a um novo patamar de legitimação.

Retomando as categorias de direitos fundamentais, Mendes compara os direitos fundamentais de defesa aos de prestação:

Se os direitos de defesa asseguram as liberdades, os direitos prestacionais buscam favorecer as condições materiais indispensáveis ao desfrute efetivo dessas liberdades. Os direitos a prestação supõem que, para a conquista e manutenção da liberdade, os Poderes Públicos devem assumir comportamento ativo na sociedade civil. ${ }^{10}$

Especificamente em relação aos direitos fundamentais de prestação e à chamada reserva do possível, a eles pertinente, os mesmos professores explicam:

Os direitos a prestação material têm a sua efetivação sujeita às condições, em cada momento, da riqueza nacional. Por isso mesmo, não seria factível que o constituinte dispusesse em minúcias, de uma só vez, sobre todos os seus aspectos. Por imposição da natureza do objeto dos direitos a prestação social, 0 assunto é entregue à conformação do legislador ordinário, confiando-se na sua sensibilidade às possibilidades de realização desses direitos em cada momento histórico. Os direitos a

${ }^{9}$ HÄBERLE, Peter. Op. cit., p. 69-70.

${ }^{10}$ MENDES, Gilmar Ferreira [et al.]. Op. cit., p. 248.

Revista de Direito, Estado e Telecomunicações, v. 3, n. 1, p. 205-280 (2011)

DOI: https://doi.org/10.26512/1str.v3i1.21671 
prestação notabilizam-se por uma decisiva dimensão econômica. São satisfeitos segundo as conjunturas econômicas, de acordo com as disponibilidades do momento, na forma prevista pelo legislador infraconstitucional. Diz-se que esses direitos estão submetidos à reserva do possível. São traduzidos em medidas práticas tanto quanto permitam as disponibilidades materiais do Estado. ${ }^{11}$

O professor Ingo Sarlet, por sua vez, opta - com fundamento em Alexy por classificar os direitos fundamentais em dois grandes grupos: os direitos de defesa e os direitos a prestações, sendo que este pode ser subdividido em direitos a prestações em sentido amplo e em sentido estrito. ${ }^{12}$

Cite-se ainda o professor Alexy, quanto à conceituação dos direitos prestacionais em sentido estrito:

Direitos a prestação em sentido estrito são direitos do indivíduo, em face do Estado, a algo que o indivíduo, se dispusesse de meios financeiros suficientes e se houvesse uma oferta suficiente no mercado, poderia também obter de particulares. Quando se fala em direitos fundamentais sociais, como, por exemplo, direitos à assistência à saúde, ao trabalho, à moradia e à educação, quer-se primariamente fazer menção a direitos a prestação em sentido estrito. ${ }^{13}$

Quanto ao grau de interferência do Estado para a concretização de direitos fundamentais, notadamente os direitos prestacionais, explica Alexy que os programas minimalista e maximalista estabelecem projetos e que, a partir de um diálogo entre eles, nota-se a impossibilidade de se resumir o problema dos direitos sociais a uma questão de tudo-ou-nada:

Vale a referência, aqui, ao professor Virgílio Afonso da Silva, no que diz respeito às origens das teorias sobre direitos fundamentais e, notadamente, a sua explicação acerca dos modos de manifestação desses direitos:

${ }^{11}$ MENDES, Gilmar Ferreira [et al.]. Op. cit., p. 250.

${ }^{12}$ SARLET, Ingo Wolfgang. A eficácia dos direitos fundamentais. $9^{\mathrm{a}} \mathrm{Ed}$. Porto Alegre: Livraria do Advogado, 2007. p. 184-185; 208-209.

${ }^{13}$ ALEXY, Robert. Teoria dos Direitos Fundamentais. Trad. Virgílio Afonso da Silva. São Paulo: Malheiros, 2008. p. 499. 
Os direitos fundamentais, junto com a separação de poderes, são conquistas essencialmente liberais e sempre serviram - não somente na sua origem, mas também nos dias atuais - como forma de evitar ingerência estatal em esferas estritamente individuais. [...] Não ignoro, obviamente, as outras "gerações" de direitos fundamentais, cuja característica principal não é a exigência de abstenções, mas, ao contrário, de prestações estatais. Isso não altera, contudo, o que foi afirmado, pois direitos fundamentais surgem como forma de proteção dos cidadãos contra violações de seus direitos por parte do Estado e essa dimensão é ainda atual (há até mesmo constituições que ainda hoje consagram apenas essa dimensão, como a alemã e a norte-americana). ${ }^{14}$

Para Sarlet, os direitos de participação fariam parte do grupo dos direitos a prestações. Além disso, o professor qualifica os direitos a prestações em originários e derivados. ${ }^{15}$ Ainda na esteira de classificação dos direitos fundamentais, o professor Ingo Sarlet utiliza-se da teoria dos status de Jellinek para separar os direitos fundamentais de cunho eminentemente negativo, ou seja, as liberdades individuais, que requerem dos poderes públicos um compromisso de não interferência, daqueles de caráter precipuamente positivo, vale dizer, direitos prestacionais, que requerem dos poderes públicos medidas ativas de prestações fático-materiais. ${ }^{16}$

${ }^{14}$ SILVA, Virgílio Afonso da. A Constitucionalização do Direito: os direitos fundamentais nas relações entre particulares. São Paulo: Malheiros, 2008. p. 128129 e nota 74. O trecho destacado corrobora, sob tal aspecto, preceito consagrado por Hans Kelsen: "A função política da Constituição é estabelecer limites jurídicos ao exercício do poder." Conferir em KELSEN, Hans. Jurisdição Constitucional. São Paulo: Martins Fontes, 2003. p. 240.

${ }^{15}$ SARLET, Ingo Wolfgang. Op. cit., p. 207-208.

${ }^{16}$ SARLET, Ingo Wolfgang. Op. cit., p. 204. Observe-se que a teoria de Jellinek parte da complementariedade entre os status positivus e negativus. Encontra resistência, porém, em teóricos como Konrad Hesse, que considera a proposição de Jellinek extremamente formal e abstrata, insuficiente, portanto, para a concretização de um conteúdo jurídico material, como se vê na seguinte passagem anotada por Sarlet (pp. 173-174): "O terceiro status referido por Jellinek - e que complementaria o status negativus - é o assim denominado status positivus (ou status civitatis), no qual ao indivíduo seria assegurada juridicamente a possibilidade de utilizar-se das instituições estatais e de exigir do Estado determinadas ações positivas. É no status positivus que se poderia, grosso modo, enquadrar os assim denominados direitos a Revista de Direito, Estado e Telecomunicações, v. 3, n. 1, p. 205-280 (2011) 
No decorrer deste capítulo, procura-se qualificar o direito à comunicação como um direito fundamental de caráter trivalente, ou seja, um direito fundamental que apresenta, em alguma medida, aspectos de defesa, de prestação e de participação. Apenas a título de introdução às próximas discussões, mencione-se o que explicam os mestres acima citados, quanto ao papel exercido pelos direitos fundamentais como diretrizes para os poderes públicos:

(...) os direitos fundamentais não se limitam à função precípua de serem direitos subjetivos de defesa do indivíduo contra atos do poder público, mas que, além disso, constituem decisões valorativas de natureza jurídico-objetiva da Constituição, com eficácia em todo o ordenamento jurídico e que fornecem diretrizes para os órgãos legislativos, judiciários e executivos. Em outras palavras, de acordo com o que consignou Pérez Luño, os direitos fundamentais passaram a apresentar-se no âmbito da ordem constitucional como um conjunto de valores objetivos básicos e fins diretivos da ação positiva dos poderes públicos, e não apenas garantias negativas dos interesses individuais, entendimento este, aliás, consagrado pela jurisprudência do Tribunal Constitucional espanhol praticamente desde 0 início de sua profícua judicatura. ${ }^{17}$

Ressalte-se, finalmente, que o conceito de direitos fundamentais do qual se parte no presente estudo é o construído por Alexy e trabalhado, na doutrina nacional, pelos professores Ingo Sarlet e Gilmar Mendes, dentre outros. Alexy considera que um direito fundamental completo é "um feixe de posições definitivas e prima facie, incluindo as relações que existem

prestações estatais, incluindo os direitos sociais, salientando-se aqui a crítica formulada pela atual doutrina no que concerne à localização dos direitos de defesa no âmbito da teoria de Jellinek. [...] Outra crítica à teoria de Jellinek que vem merecendo a atenção da doutrina foi formulada por K. Hesse, para o qual o status constitucional do indivíduo garantido pelos direitos fundamentais não constitui uma situação meramente formal, relativa ao indivíduo abstrato (como é o caso do status negativus de Jellinek), mas, sim, um status jurídico material, com conteúdo concreto e determinado, que não se encontra à disposição ilimitada nem do indivíduo nem dos poderes públicos."

${ }^{17}$ MENDES, Gilmar Ferreira [et al.]. Op. cit., p. 159. 
entre elas ${ }^{18}$." Esse conceito é desenvolvido pelo seguinte trecho, também do professor alemão:

0 direito fundamental completo é algo bastante complexo, mas em hipótese alguma um objeto inescrutável. Ele é composto de elementos de estrutura bem definida - das posições individuais dos cidadãos e do Estado -, e entre essas posições há relações claramente definíveis - as relações de especificação, de meio-fim e de sopesamento. ${ }^{19}$

Tais considerações mereceram referência justamente porque, a partir deste ponto, os direitos fundamentais serão analisados com base em tais características que os definem, a fim de se chegar à qualificação do direito à comunicação como direito fundamental, integrante da Constituição material brasileira e apto a assegurar uma posição jurídica indispensável ao cidadão brasileiro, integrante de uma sociedade em transição para a sociedade informacional em rede.

\section{Direitos fundamentais: abertura e necessidade de atualização de seu catálogo}

A Constituição Federal de 1998 consagrou, em seu artigo $5^{\circ}$, § $2^{\circ}$, a chamada abertura do sistema de direitos fundamentais. Mendes, Gonet e Coelho retratam com precisão o fato de que o caráter fundamental de um direito não decorre de sua presença expressa no rol constitucional, mas de sua essência, principalmente no que toca à dignidade da pessoa humana. Assim é que, a despeito da ausência de previsão constitucional, um direito pode ser materialmente fundamental, desde que corrobore os princípios da Constituição vigente. ${ }^{20}$

A mencionada abertura, consagrada no texto constitucional, decorre da necessidade de atualização do rol de direitos fundamentais em face das transformações experimentadas pela sociedade. É que uma nova realidade faz emergirem novas necessidades humanas e novos direitos fundamentais;

\footnotetext{
${ }^{18}$ ALEXY, Robert. Op. cit., p. 252.

${ }^{19}$ ALEXY, Robert. Teoria dos Direitos Fundamentais. Trad. Virgílio Afonso da Silva. São Paulo: Malheiros, 2008. Pp. 253.

${ }^{20}$ MENDES, Gilmar Ferreira [et al.]. Op. cit., p. 260.
}

Revista de Direito, Estado e Telecomunicações, v. 3, n. 1, p. 205-280 (2011)

DOI: https://doi.org/10.26512/1str.v3i1.21671 
de igual modo e em contrapartida, surgem também novas possibilidades de ofensa aos novos e basilares direitos.

Desse modo, transformações políticas, econômicas, culturais ou de qualquer ordem podem suscitar a necessidade de se consagrarem novos direitos como fundamentais, a fim de garantir a participação dos cidadãos no novo modelo social inaugurado por tal evolução.

A própria concepção de sucessivas e complementares gerações - ou dimensões, como prefere parte da doutrina - de direitos fundamentais indica a constante atualização do catálogo, indispensável para a manutenção da relevância da categoria, vez que o direito exerce seu papel social apenas quando se mantém a par das demandas existentes à época.

Por razões óbvias, no entanto, é necessário haver cautela no que se refere à qualificação de um direito como fundamental. É que, como explica o professor Sarlet - referindo-se ao mestre Perez Luño -, a "fundamentalização" de todo e qualquer direito significaria verdadeira banalização da categoria de direitos fundamentais. ${ }^{21}$

Ressalte-se desde já que, nesse contexto de dimensões de direitos fundamentais e de atualização de seu catálogo, o direito à comunicação pode ser encaixado como um direito de terceira dimensão, como direito de fraternidade ou solidariedade, pois se desprende, "em princípio, da figura do homem-indivíduo como seu titular, destinando-se, consequentemente, como direitos de titularidade coletiva ou difusa." 22

Finalmente, quanto aos novos direitos, emergentes das alterações por que passa a sociedade, merece destaque uma referência ao fato de que o reconhecimento do caráter fundamental destes não se dá, necessariamente, de forma instantânea. Tem-se, em verdade, um processo continuado, no que se pode caracterizar como matéria de Law in making.

De toda sorte, tais matérias mostram-se indispensáveis ao progresso e ao desenvolvimento humano, justamente por atualizarem o marco jurídico quanto às demandas sociais hodiernas, atribuindo, portanto, caráter dinâmico ao ordenamento.

Quanto ao avanço dos direitos fundamentais em paralelo ao desenvolvimento da sociedade e ao surgimento de novos conjuntos de

${ }^{21}$ SARLET, Ingo Wolfgang. Op. cit., p. 61-62.

${ }^{22}$ SARLET, Ingo Wolfgang. Op. cit., p. 56.

Revista de Direito, Estado e Telecomunicações, v. 3, n. 1, p. 205-280 (2011) DOI: https://doi.org/10.26512/lstr.v3i1.21671 
valores em relação aos quais o direito busca atuar de forma relevante, a visão de sucessivas gerações ou dimensões de direitos fundamentais é criticada também sob a ótica da hierarquia, ainda que inconsciente, estabelecida entre os grupos de direitos classificados. ${ }^{23}$

No caso específico do direito à comunicação e, dentro de sua esfera, notadamente a garantia do acesso à internet, é ainda mais evidente a sua afirmação como direito fundamental frente à necessária inclusão digital hoje propalada.

Mencione-se, aliás, que a tomada de decisões políticas relevantes, como categoria na qual se enquadra a opção de se considerar um direito como materialmente fundamental, a despeito de não integrar o catálogo constitucional, ${ }^{24}$ é tratada por Karl Loewenstein como um momento decisivo para dada comunidade:

Como decisões políticas fundamentais, devem se considerar aquelas resoluções da sociedade que são decisivas e determinantes, no presente e frequentemente no futuro, para a conformação de certa comunidade. ${ }^{25}$

A partir deste ponto, portanto, buscar-se-á inserir o direito à comunicação como direito considerado materialmente fundamental, à luz da Constituição, conforme os critérios de fundamentalidade a seguir expostos.

\section{Critérios de fundamentalidade formal e material}

Segundo Loewenstein:

Para que uma constituição seja viva, deve ser efetivamente vivida por destinatários e detentores do poder (...). Para que uma constituição seja viva, não é suficiente que seja válida no sentido jurídico. Para ser real e

${ }^{23}$ CUNHA, Paulo Ferreira da. Direito à informação ou deveres de protecção informativa do Estado? In: SARLET, Ingo Wolfgang (org.) [et al.]. Direitos Fundamentais, Informática e Comunicação: algumas aproximações. Porto Alegre: Livraria do Advogado, 2007. p. 158.

${ }^{24}$ Temática trabalhada com maior clareza no tópico seguinte, no qual se discutem os critérios de fundamentalidade formal e material.

${ }^{25}$ LOEWENSTEIN, Karl. Teoría de la Constitución. Trad. Alfredo Gallego Anabitarte. $2^{a}$ ed. Barcelona: Editorial Ariel, 1986. p. 63. Tradução livre.

Revista de Direito, Estado e Telecomunicações, v. 3, n. 1, p. 205-280 (2011)

DOI: https://doi.org/10.26512/1str.v3i1.21671 
efetiva, a constituição terá de ser observada lealmente por todos os interessados e terá de estar integrada à sociedade estatal, e esta naquela. A constituição e a comunidade devem ter passado por simbiose. ${ }^{26}$

De maneira semelhante ao desenvolvimento doutrinário dos conceitos de constituição formal e material, em classificação que cuida da efetividade do texto constitucional e de suas normas e do conteúdo destas ${ }^{27}$, também os direitos fundamentais são categorizados em direitos formal e materialmente fundamentais.

Em geral, tem-se que os direitos expressamente previstos no catálogo constitucional são, em geral, classificados como formal e materialmente fundamentais, mas há direitos que, a despeito de não integrarem o rol constitucional, merecem, por seu conteúdo, a marca da fundamentalidade.

${ }^{26}$ LOEWENSTEIN, Karl. Op. cit., p. 217. Tradução livre. Uma ideia semelhante pode ser encontrada na seguinte passagem de Konrad Hesse: "Embora a Constituição não possa, por si só, realizar nada, ela pode impor tarefas. A Constituição transforma-se em força ativa se essas tarefas forem efetivamente realizadas, se existir a disposição de orientar a própria conduta segundo a ordem nela estabelecida, se, a despeito de todos os questionamentos e reservas provenientes dos juízos de conveniência, se puder identificar a vontade de concretizar essa ordem. Concluindo, pode-se afirmar que a Constituição converter-se-á em força ativa se fizerem-se presentes, na consciência geral - particularmente, na consciência dos principais responsáveis pela ordem constitucional -, não só a vontade de poder (Wille zur Macht), mas também a vontade de Constituição (Wille zur Verfassung). HESSE, Konrad. A força normativa da Constituição. Trad. Gilmar Ferreira Mendes. Porto Alegre: Sergio Antonio Fabris Editor, 1991. p. 19.

${ }^{27}$ Sobre as origens das discussões acerca da chamada constituição material, ver: LOEWENSTEIN, Karl. Teoría de la Constitución. Trad. Alfredo Gallego Anabitarte. $2^{\mathrm{a}}$ ed. Barcelona: Editorial Ariel, 1986. Especial referência ao seguinte trecho: "A necessidade de formular e, portanto, formalizar a ordem fundamental da sociedade estatal em um documento sério - constituição em sentido formal - como um sistema, sem lacunas, de normas fundamentais é um desenvolvimento relativamente posterior do constitucionalismo. Assim, isso não foi postulado pelo constitucionalismo dos gregos e romanos. Para Platão e Aristóteles, assim como em toda teoria política grega, a politeia foi a constituição em sentido material.” (p. 152). $\mathrm{O}$ autor prossegue, analisando ainda os desdobramentos das revoluções puritana, americana e francesa, para então chegar aos considerados elementos fundamentais que constituem um núcleo irredutível mínimo de uma autêntica constituição. 
Um direito é considerado formalmente fundamental quando recebe tal qualificação por ordem expressa do legislador-constituinte, enquanto o caráter de direito materialmente fundamental depende, sobretudo, de tal garantia ser parte integrante da Constituição material, em face de sua essência e substância exigirem dito reconhecimento. ${ }^{28}$

Assim, à luz de tal posicionamento, o professor Ingo defende que há direitos fundamentais situados fora do catálogo, sendo que estes podem estar ou não previstos na Constituição formal. A restrição feita, porém, é que, para um direito ser considerado materialmente fundamental estando fora do rol constitucional, deverá "equivaler - em seu conteúdo e dignidade - aos direitos fundamentais do catálogo."29

Dessa feita, com base em Robert Alexy, Sarlet define direitos fundamentais como posições jurídicas que, de fato, podem ser consideradas - seja nos aspectos formal e material ou tão-somente no aspecto material parte integrante da Constituição, em função do valor a elas inerente, reconhecido ou não pelo legislador-constituinte. ${ }^{30}$

$\mathrm{O}$ direito à comunicação, como se vê, emerge como um direito materialmente fundamental, sobretudo em razão de sua substância e relevância, que é crescente no contexto da sociedade em rede.

\section{Conceito de direito à comunicação e sua previsão na Constituição de 1988}

O direito à comunicação é há muito reconhecido como um direito basilar da pessoa humana, em face da percepção comum da necessidade de se assegurar a liberdade de interação entre os indivíduos como elemento imprescindível da cidadania, tendo sido incluído na clássica Declaração dos Direitos do Homem e do Cidadão de 1789:

Art. 11. A livre comunicação das ideias e das opiniões é um dos mais preciosos direitos do homem; todo cidadão pode, portanto, falar, escrever, imprimir livremente, respondendo, todavia,

\footnotetext{
${ }^{28}$ SARLET, Ingo Wolfgang. A eficácia dos direitos fundamentais. $9^{\mathrm{a}}$ Ed. Porto Alegre: Livraria do Advogado, 2007. p. 86-87.

${ }^{29}$ SARLET, Ingo Wolfgang. Op. cit., p. 103.

${ }^{30}$ SARLET, Ingo Wolfgang. Op. cit., p. 89.

Revista de Direito, Estado e Telecomunicações, v. 3, n. 1, p. 205-280 (2011)

DOI: https://doi.org/10.26512/1str.v3i1.21671
} 
pelos abusos desta liberdade nos termos previstos na lei.

(Declaração dos Direitos do Homem e do Cidadão de 1789)

A despeito das diversas possibilidades de se abordar o conceito de direito à comunicação, é possível identificar que, principalmente após a elaboração do Relatório Macbride, de 1980, pela UNESCO, esse direito tem sido encarado como um direito de "mão dupla", como explica Miriam Wimmer:

(...) tem-se vindo a encarar o direito à comunicação como um direito "de mão dupla", que permite aos cidadãos não apenas receber estaticamente informações selecionadas por terceiros, mas, sobretudo, interagir, participar e decidir com liberdade sobre as informações que desejam acessar e as opiniões que desejam emitir. Tem-se vindo a considerar a necessidade de proteger não apenas o conteúdo da comunicação, mas 0 próprio processo de comunicação e a distribuição eqüitativa dos recursos de comunicação. ${ }^{31}$

O referido Relatório retratou estudo que teve por objeto a análise de como se dava a comunicação no mundo, sobretudo a partir do ponto de vista do acesso à informação e da difusão do conhecimento quanto aos meios de comunicação de massa e à imprensa internacional.

Desde então, a noção de direito à comunicação passou a envolver necessariamente a possibilidade de interação do indivíduo com um ambiente multifacetado de constantes trocas de dados e experiências, a partir de um mecanismo de recebimento, emissão e transmissão de informações diversas. Trata-se, como explica Wimmer, de uma proteção ao conteúdo e ao processo de comunicação, além de se buscar a distribuição equânime dos recursos de comunicação.

A relevância do direito à comunicação é tanto maior quanto mais se verifica a importância dos instrumentos a ele relacionados para a efetiva participação dos indivíduos e dos grupos sociais no processo democrático, bem como para o necessário desenvolvimento humano, intimamente ligado, no contexto da sociedade em rede, ao acesso às novas tecnologias, como a internet.

\footnotetext{
${ }^{31}$ WIMMER, Miriam. O direito à comunicação na Constituição de 1988: o que existe e o que falta concretizar. In: Eco-Pós (UFRJ), v. 11, p. 146-165, 2008. p. 147.
} 
O conceito hodierno de direito à comunicação, portanto, sobrepõe-se ao de direito à informação, entendido este como um direito de "mão única", que assegura apenas o acesso às informações colocadas à disposição por terceiros, sem, no entanto, garantir também a possibilidade de o indivíduo criar e produzir conhecimento, divulgá-lo e interagir a respeito dele com outros, em um processo amplo e diverso de comunicação.

A partir desse entendimento atual, é possível identificar na Constituição Federal de 1988 duas dimensões de tutela do direito à comunicação: uma individual e outra social. Miriam Wimmer explica que a dimensão individual dos direitos à comunicação abrange disposições relativas "à posição subjetiva do indivíduo face ao Estado, relativas à informação e à expressão pessoal." 32 Já a dimensão social envolve as diretrizes que cuidam da "tutela dos meios de comunicação de massa, incluindo os direitos de participação." "33

Quanto à dimensão individual do direito à comunicação, destacam-se as disposições constitucionais referentes às liberdades que envolvem $\mathrm{o}$ desenvolvimento e a expressão ou difusão do pensamento e da informação, tradicionalmente classificadas como direitos de defesa, por constituírem verdadeiras garantias de não-interferência e não-censura frente ao Estado.

Assim, a Constituição trata, no artigo $5^{\circ}$, inciso IV, da liberdade de manifestação do pensamento e, no mesmo artigo, no inciso IX, da livre expressão da atividade intelectual, artística, científica e de comunicação. Acerca dessas disposições, esclarece Wimmer:

A observância a tais direitos é assegurada pela vedação à censura de qualquer natureza e pela dispensa de qualquer licença para o exercício da liberdade de expressão e têm, como contrapartida, a vedação ao anonimato (art. $5^{\circ}$, inciso IV, segunda parte) e a garantia do direito de resposta e de indenização por dano material, moral ou à imagem (art. $5^{\circ}$, inciso V). Tais contrapartidas alinham-se com a garantia constitucional à inviolabilidade da intimidade, da vida privada, da honra e da imagem (art. $5^{\circ}$, inciso X). ${ }^{34}$

\footnotetext{
${ }^{32}$ WIMMER, Miriam. Op. cit., p. 155.

${ }^{33}$ WIMMER, Miriam. Idem.

${ }^{34}$ WIMMER, Miriam. Op. cit., p. 156.

Revista de Direito, Estado e Telecomunicações, v. 3, n. 1, p. 205-280 (2011)

DOI: https://doi.org/10.26512/1str.v3i1.21671
} 
Outros aspectos da dimensão individual do direito à comunicação são arrolados pelo texto constitucional, relativos aos princípios da transparência e da publicidade, a que se submetem os atos da Administração Pública, nos termos do artigo 37.

Tais princípios proporcionam aos cidadãos direitos de caráter prestacional, como os assegurados pelos incisos XIV e XXXIII do artigo $5^{\circ}$ : direito de acesso à informação e resguardo do sigilo da fonte e direito de receber de órgãos públicos informações de interesse particular, ou de interesse coletivo ou geral, respectivamente, sendo cabível, neste último caso, a impetração de habeas data para a sua efetivação, além da própria possibilidade de exercício do direito de petição.

Já no tocante à dimensão social do direito à comunicação, verifica-se que a Constituição reservou o Capítulo V, do Título VIII, à comunicação de massa, sendo que o seu primeiro dispositivo, consubstanciado no artigo 220, estabelece:

Art. 220. A manifestação do pensamento, a criação, a expressão e a informação, sob qualquer forma, processo ou veículo não sofrerão qualquer restrição, observado 0 disposto nesta Constituição.

Wimmer explica que, no caso deste princípio, prevê-se "uma liberdade de expressão qualificada pelo meio de transmissão do conteúdo comunicativo, especificamente direcionada para os meios de comunicação de massa." ${ }^{35}$ Também aqui se encontra um direito de liberdade ou de defesa, que impõe barreiras à ingerência estatal, repercutindo nas vedações dispostas nos parágrafos do mesmo artigo e em outras proteções, como a imunidade tributária relativa à instituição de impostos sobre livros, jornais, periódicos e o papel destinado a sua impressão (artigo 150, VI, $d$ ).

Ao lado dessas garantias de defesa, a Constituição estabelece também deveres ao legislador ordinário, no sentido de regulamentar "diversões e espetáculos com vistas à proteção da infância e juventude de conteúdos inapropriados", além de regular a defesa "contra programas ou programações que violem os valores éticos e sociais da pessoa e da família e

${ }^{35}$ WIMMER, Miriam. Op. cit., p. 157. 
contra a propaganda de produtos, práticas e serviços que possam ser nocivos à saúde ou ao meio ambiente (art. 220, $\S \S 3^{\circ}$ e $4^{\circ}$ e art. 221)." 36

Ainda no campo da dimensão social do direito à comunicação, vê-se que foram consagrados também pela Carta Magna os direitos ao pluralismo das fontes e ao pluralismo das informações, que implicam "deveres de legislação e de implementação de políticas públicas para o Estado e deveres de sujeição ou tolerância para os detentores dos meios de comunicação." 37

Do pluralismo das fontes decorre a vedação ao monopólio ou oligopólio nos meios de comunicação social, previsto no artigo 220 , § $5^{\circ}$, e o “(...) princípio da complementaridade entre sistemas privado, público e estatal de radiofusão", que, “(...) em conjunto com as normas infraconstitucionais relativas à radiodifusão comunitária, permitem, em tese, que as informações veiculadas nos meios de comunicação social provenham de origens diversificadas (art. 223). ${ }^{.38}$

Em relação ao pluralismo das informações, a Constituição prevê, no artigo 221, diretrizes para a produção e a programação das emissoras de rádio e televisão e sobre os demais meios de comunicação social eletrônica (art. 222, $\S 3^{\circ}$ ), bem como normas que tratam da propriedade de empresas jornalísticas e de radiodifusão, estabelecidas nos parágrafos $1^{\circ}$ e $2^{\circ}$ do artigo 222.

Wimmer descreve ainda outros dispositivos de grande relevância, referentes ao direito de antena e ao caráter de serviços públicos conferido a determinados serviços de telecomunicações:

A possibilidade de veiculação de opiniões diversificadas, especificamente no plano político, é ainda assegurada por meio da consagração do direito de antena ( $\operatorname{art} .17, \S 3^{\circ}$ ), atualmente limitado aos partidos políticos. Além disso, a Constituição previu a instituição de um Conselho de Comunicação Social que, em tese, serviria como mecanismo de democratização e permeabilização da comunicação social à sociedade civil (art. 224). Por fim, a especial relevância dos direitos associados à comunicação social é reforçada pela atribuição, a determinados serviços de telecomunicações e de radiodifusão, da natureza de serviços públicos,

\footnotetext{
${ }^{36}$ WIMMER, Miriam. Op. cit., p. 157-158.

${ }^{37}$ WIMMER, Miriam. Op. cit., p. 158.

${ }^{38}$ WIMMER, Miriam. Op. cit., p. 159.
}

Revista de Direito, Estado e Telecomunicações, v. 3, n. 1, p. 205-280 (2011)

DOI: https://doi.org/10.26512/lstr.v3i1.21671 
de titularidade da própria União (art. 21, incisos XI e XII, alínea "a"). No caso da radiodifusão, há, ainda, regras específicas de tramitação dos procedimentos de outorga e renovação das concessões, envolvendo a participação obrigatória do Congresso Nacional (art. 223). ${ }^{39}$

Nota-se, desse modo, que a Constituição Federal de 1988 possui um farto instrumental no que toca ao direito à comunicação e a garantias a ele associadas. Pode-se afirmar, com tranquilidade, que o direito à comunicação, embora não expressamente consagrado pelo texto constitucional, é um direito materialmente fundamental, que encontra respaldo no conjunto de princípios relativos à comunicação social e às liberdades de expressão de pensamento e de acesso à informação, formalmente previstos na Carta vigente.

\section{O direito à comunicação e o Estado: um direito fundamental trivalente}

Como já antecipado, o direito à comunicação envolve aspectos próprios dos chamados direitos de defesa, ao mesmo tempo em que apresenta características peculiares aos direitos prestacionais e aos direitos de participação. Viu-se ainda que o direito à comunicação é um direito materialmente fundamental, em face do conjunto principiológico e normativo referente à liberdade de expressão e à comunicação social da Constituição de 1988. Daí optar-se por qualificar o direito à comunicação, para os fins desta pesquisa, como um direito fundamental trivalente.

É possível encontrar referências doutrinárias que se restringem a classificar o direito à comunicação como um direito de defesa, equiparandoo ao direito à informação - que, como mencionado anteriormente, pode ser descrito como um direito de "mão única", enquanto o direito à comunicação foi apresentado como um "direito de mão dupla".

A abordagem que se propõe aqui, entretanto, pressupõe o entendimento de boa parte da doutrina contemporânea no sentido de admitir que o direito à comunicação apresenta caráter multifacetado, na medida em que os aspectos de defesa (ou liberdade), prestação e participação interagem constantemente na criação de um direito fundamental completo e eficaz, sobretudo no

\footnotetext{
${ }^{39}$ WIMMER, Miriam. Idem.
} 
momento histórico atual e, com peculiaridades destacadas mais adiante, em uma sociedade em transição para a sociedade em rede como a brasileira. Em decorrência desta posição, a maneira pela qual o Estado enxerga o direito à comunicação e atua para lhe conferir eficácia é alterada.

Opta-se por esse posicionamento em face do papel cada vez mais significativo ocupado pelas comunicações no cotidiano da sociedade atual, especialmente no que diz respeito à construção de um espaço público informado como passo relevante para a consolidação de uma democracia nacional. Nas palavras do mestre Lopez-Ayllón: "Com efeito, a vida democrática depende da construção de um espaço público informado." 40

Deve-se, desse modo, fazer uma primeira referência, à luz do ensino do professor Paulo Ferreira da Cunha, a respeito do caráter trivalente do direito fundamental à comunicação:

Assim, a Liberdade, pelo menos a liberdade civil e política, começa, em grande medida, com a liberdade de expressão e comunicação. Uma vez assegurado o pressuposto dos direitos todos que é a vida, garantida a integridade física e psíquica q. b., e a liberdade geral de movimentos (sem constrições gritantes, sem cativeiro), o momento primeiro de livre desenvolvimento da personalidade em que se analisa a dignidade humana em ação será 0 livre interagir com 0 seu semelhante. ${ }^{41}$

A partir do trecho destacado, é possível identificar que o primeiro passo para se emprestar eficácia ao direito à comunicação é o respeito aos aspectos de direito de defesa que lhe são inerentes. Isso porque, como bem expõe o professor Paulo da Cunha, o livre desenvolvimento da personalidade, elemento primordial da dignidade da pessoa humana, passa, necessariamente, pela liberdade para o estabelecimento de interações com outros indivíduos, como concretização do homo socialis.

Este aspecto implica ao Estado obrigações de não intervenção, não censura, enfim, deveres de afastamento no sentido de permitir a livre

${ }^{40}$ LOPEZ-AYLLÓN, Sergio. El derecho a la información como derecho fundamental. In: Derecho a la información y derechos humanos. CARPIZO, Jorge; CARBONELL, Miguel (org.). Ciudad del Mexico: Universidad Nacional Autónoma de Mexico, 2000. p. 179. Tradução livre.

${ }^{41}$ CUNHA, Paulo Ferreira da. Op. cit., p. 162.

Revista de Direito, Estado e Telecomunicações, v. 3, n. 1, p. 205-280 (2011)

DOI: https://doi.org/10.26512/1str.v3i1.21671 
comunicação entre os indivíduos, pelo exercício de suas autonomias privadas. Na mesma linha lecionam os professores Gilmar Mendes, Paulo Branco e Inocêncio Coelho, a respeito da liberdade de expressão:

Incluem-se na liberdade de expressão faculdades diversas, como a de comunicação de pensamento, de ideias, de informações e de expressões não verbais (comportamentais, musicais, por imagem, etc.). 0 grau de proteção que cada uma dessas formas de se exprimir recebe costuma variar, mas, de alguma forma, todas elas estão amparadas pela Lei Maior. Compreender os fundamentos que se designam como justificativa para a proteção da liberdade de expressão é útil quando se enfrentam problemas relacionados com 0 âmbito normativo desse direito básico. A plenitude da formação da personalidade depende de que se disponha de meios para conhecer a realidade e as suas interpretações, e isso como pressuposto mesmo para que se possa participar de debates e para que se tomem decisões relevantes. ${ }^{42}$

Ressalte-se, quanto ao ponto, que os mesmos professores se preocupam em caracterizar a liberdade de expressão como um direito estritamente de defesa, do qual o cidadão é titular frente ao Estado. Assim, negam a possibilidade de se atribuir um caráter positivo à liberdade de expressão no sentido de garantir o acesso a meios de comunicação para veiculação de ideias e notícias:

Além do direito de acesso à mídia por quem foi nela afrontado, haveria outro direito de expor ideias e notícias em órgãos de comunicação, a pretexto de exercício da liberdade de expressão? A indagação tem encontrado resposta negativa. Vem prevalecendo uma interpretação mais restrita da garantia constitucional da liberdade de expressão. Não se vê suporte nesse direito fundamental para exigir que terceiros veiculem as ideias de uma dada pessoa. A liberdade se dirige, antes, a vedar que 0 Estado interfira no conteúdo da expressão. 0 direito não teria por sujeito passivo outros particulares, nem geraria uma obrigação de fazer para 0 Estado. 0 princípio constitucional da livre iniciativa e mesmo o direito

${ }^{42}$ MENDES, Gilmar Ferreira [et al.] p. 350.

Revista de Direito, Estado e Telecomunicações, v. 3, n. 1, p. 205-280 (2011) 
de propriedade desaconselhariam que se atribuísse tamanha latitude a essa liberdade. ${ }^{43}$

De outra banda, nota-se que o direito à comunicação parte do ideal da liberdade de expressão para demandar do Estado condutas positivas ou prestacionais, a fim de que a manifestação do pensamento, o acesso à informação, a possibilidade de criação e divulgação do seu produto, enfim, todos os elementos que o compõem sejam de fato efetivamente experimentados pelos titulares do direito.

Os estudos do professor Paulo da Cunha mostram com clareza os conflitos que emergem dessa necessidade de que o Estado atue na direção de proporcionar os meios indispensáveis à concretização desse direito de comunicar - no sentido amplo e multidirecional aqui adotado:

Uma coisa será sempre pensar o problema a partir 'de cima', do Estado, dessa lógica hierarquizada e unilateral, ainda que de um centro para várias periferias, de um emissor para vários receptores, mais ou menos estratificados, filtrados por diferentes estatutos jurídicos e sociais, e outra fazê-lo tendo como base a questão da liberdade de informar, de produzir conteúdos significativos e socialmente transmissíveis, de comunicar. ${ }^{44}$

O que se percebe a partir da afirmativa acima é que, se se admitir a liberdade de informar e de produzir conteúdos, bem como de os transmitir a outros, como o centro do problema relativo à participação estatal para tornar eficaz o direito à comunicação, far-se-á necessário admitir também que o Estado não pode se eximir, sob a justificativa de se tratar de um direito de cunho eminentemente negativo, de promover as condições elementares para o gozo real do direito à comunicação.

Cunha explicita o papel elementar do Estado no sentido de ao menos assegurar, para a concretização do direito à informação, como direito associado à liberdade de expressão e comunicação, a transparência

\footnotetext{
${ }^{43}$ MENDES, Gilmar Ferreira [et al.] p. 354. Ressalte-se, contudo, que a perspectiva adotada pelos referidos professores é a da comunicação de massa, e não a da sociedade em rede, como faz este estudo ${ }^{44}$ CUNHA, Paulo Ferreira da. Op. cit., p. 165.
}

Revista de Direito, Estado e Telecomunicações, v. 3, n. 1, p. 205-280 (2011)

DOI: https://doi.org/10.26512/1str.v3i1.21671 
administrativa, o acesso a documentos, entre outras garantias. ${ }^{45}$ Vê-se, portanto, que mesmo o aspecto de direito de defesa referente ao direito à comunicação requer dos poderes públicos certa medida de atuação positiva.

Daí também ser cabível dizer que o mesmo doutrinador português manifesta inquietação quanto à possibilidade de que o direito à informação denominação que acentua o aspecto de defesa do direito, ao contrário da expressão "direito à comunicação" - leve à compreensão de que os sujeitos assumam caráter passivo, em face do poder exercido pelos entes públicos ou pelos grandes organismos privados, no sentido de regular ou determinar os conteúdos informativos. ${ }^{46}$

De qualquer forma, nota-se a necessidade de intervenção estatal para emprestar eficácia ao elemento negativo ou de defesa do direito à comunicação, manifestado na liberdade de expressão e no acesso à informação. É o que conclui Paulo Ferreira da Cunha:

Assim, para garantir o acesso à informação, por exemplo, o Estado tem de ser muito interventor: de forma a que largas camadas de excluídos sociais, excluídos culturais, tenham meios materiais, e ócio criativo e digno que os leve a consumir e até a criar informação. Aqui o direito à informação efectivo sobrepuja largamente a liberdade de informação meramente passiva, que alguns diriam simplesmente 'liberal' hoc sensu. [...] Não cabe, no fundamental princípio da equidade informativa, o dever de o Estado dotar cada desprotegido de um canal de televisão mundial para que exponha o seu pensamento a todos os habitantes da Terra. Mas poderá legislar no sentido de que, por hipótese, um humilde utente dos transportes colectivos de uma pequena localidade eficazmente e em tempo útil veja a sua reclamação pública reiterada sobre a demora dos ônibus publicada no jornal local, com os seus comentários urbanos, ainda que indignados. ${ }^{47}$

Ingressa-se, assim, nos elementos prestacionais do direito à comunicação, compostos por um conjunto de deveres que se pode impor ao Estado no sentido não apenas de se omitir a fim de permitir a liberdade de expressão e de manifestação do pensamento, mas também de assegurar e

${ }^{45}$ CUNHA, Paulo Ferreira da. Op. cit., p. 168.

${ }^{46}$ CUNHA, Paulo Ferreira da. Op. cit., p. 169.

${ }^{47}$ CUNHA, Paulo Ferreira da. Op. cit., p. 171. 
proporcionar os meios e os suportes tecnológicos indispensáveis à concretização de tais liberdades.

O professor Têmis Limberger elucida a questão:

Pode-se concluir que a tutela dos direitos da pessoa deve ser compatibilizada com as exigências do mundo atual, que almeja a liberdade de informação e a livre circulação dos dados. Em última análise, a informática é algo que já se incorporou na vida quotidiana moderna. Hoje, não se vislumbra retrocesso. 0 desafio é como proteger os dados informatizados frente a uma sociedade e um mercado cada vez mais livres de fronteiras. A globalização pressupõe e propõe uma economia sem fronteiras e sem regulamentação. No entanto, não se pode desprezar anos de construção de direitos fundamentais e mudar tudo isso por uma única lei: a lei de mercado e a ilusão de que o mercado tudo regulará. 0 grande desafio que se impõe no plano dos direitos fundamentais é como fazer com que não somente o capital e os bens de consumo circulem em todo o mundo, mas também os direitos. ${ }^{48}$

Nessa linha, percebe-se que a realidade do mundo interligado pelas redes de comunicação oferece o desafio à situação de proteção dos direitos fundamentais, uma vez que esses direitos precisam ser respeitados sem que as próprias fronteiras geográficas que os localizam e condicionam sejam observadas pelos tráfegos de dados e informações.

Por isso, a relação do Estado com o particular e a maneira pela qual o Estado estabelece a proteção e assegura a concretização de direitos como o direito à comunicação passa, necessariamente, por transformações, inclusive na perspectiva sugerida de se enxergar, no caso, o direito à comunicação como um direito fundamental que apresenta, simultaneamente, elementos de direito de defesa, de prestação e de participação. Quanto a esse desafio, é particularmente importante a lição do professor Jónatas Machado:

De resto, tem sido salientada a diversidade dos interesses individuais e colectivos que estão em causa no âmbito das liberdades comunicativas,

${ }^{48}$ LIMBERGER, Têmis. Direito e informática: o desafio de proteger os direitos do cidadão. In: SARLET, Ingo Wolfgang (org.). Direitos Fundamentais, Informática e Comunicação: algumas aproximações. Porto Alegre: Livraria do Advogado, 2007. p. 225.

Revista de Direito, Estado e Telecomunicações, v. 3, n. 1, p. 205-280 (2011)

DOI: https://doi.org/10.26512/1str.v3i1.21671 
que incluem o direito de ser informado, divertido, estimulado das mais variadas formas, e mesmo provocado, sempre que isso possa conduzir à reflexão, à crítica e ao crescimento emocional e intelectual. A multiplicidade e multiformidade desses interesses tem contribuído para a expansão dos meios de comunicação social, muito para além do serviço público de radiodifusão. Numa ordem constitucional livre e democrática, as liberdades de opinião e de informação pressupõem a protecção das diferentes liberdades e tecnologias da comunicação e um forte incentivo à inovação, de forma a permitir o livre e dinâmico exercício das actividades de imprensa, rádio, televisão, incluindo a televisão por cabo, por satélite, digital de alta definição, juntamente com o cinema, o vídeo, a internet e as telecomunicações, em várias modalidades e combinações, sem as quais perdem uma parte substancial do seu sentido. ${ }^{49}$

Nota-se que essa expansão dos meios de comunicação e as transformações tecnológicas correspondentes geram, de fato, uma necessidade de incentivo e fomento a novas manifestações de criação e produção de informação e conhecimento, o que significa essencialmente uma indispensável atuação estatal na direção de viabilizar tais meios aos cidadãos.

Contudo, como outro componente dessa trivalência do direito à comunicação é justamente a participação, vê-se que a responsabilidade do Estado abrange ainda um dever de redimensionar os espaços públicos de atuação política a partir das novas realidades implantadas pela evolução das comunicações.

É que, como bem esclarece o professor Alexandre Faraco:

Não se trata apenas de expandir o uso de uma nova forma de comunicação ou o acesso a informações em geral, mas de potencialmente se gerar modos diversos de produção e difusão de informações e de organização política que permitam contrapor as estruturas de poder existentes, além de viabilizar novas formas de atuação sobre 0 espaço público aos mais diversos grupos sociais. Assim, o foco da discussão de políticas públicas de comunicação em países em desenvolvimento

\footnotetext{
${ }^{49}$ MACHADO, Jónatas E. M. Liberdade de programação televisiva: notas sobre os seus limites constitucionais negativos. In: SARLET, Ingo Wolfgang (org.). Op. cit., p. 107.
} 
deveria centrar-se em torno desses dois vetores (i.e., o controle do poder dos meios de comunicação tradicionais e a difusão do acesso ao uso de novas tecnologias). ${ }^{50}$

Faraco propõe, nessa perspectiva, que a análise da questão da implementação de políticas públicas de comunicação nos países em desenvolvimento seja feita do ponto de vista do redimensionamento dos espaços públicos de comunicação, o que passa, obrigatoriamente, pela discussão do controle do poder exercido pelos meios tradicionais de comunicação, e pela difusão do acesso ao uso das tecnologias mais atuais.

Essa proposta indica o caminho traçado para o último capítulo deste trabalho, o qual procurará desenvolver uma análise acerca das iniciativas e dos projetos que cuidam da massificação do acesso à internet, a partir do quadro hoje existente no Brasil, para então se discutir a eficácia e a penetração dessas medidas em relação à finalidade de se concretizar o direito fundamental à comunicação.

O trajeto delineado, que passa necessariamente pela análise do papel ocupado pela internet na sociedade hodierna, justifica-se, entre outras razões, pelo motivo descrito nas seguintes palavras do professor Paulo da Cunha: "Mesmo enquanto muitas das variáveis referidas não se verificam, a internet é o espaço possível de mais vasta liberdade de informação em todos os sentidos." $" 51$

É certo, de todo modo, que a transformação por que passa o mundo em face da revolução das comunicações é mais profunda do que normalmente tem sido dito, sobretudo quanto à importância de que as políticas regulatórias e as instituições e normas jurídicas se adaptem às demandas sociais emergentes, como explica o professor Lopez-Ayllón:

Por outro lado, as inovações tecnológicas que ocorrem desde os últimos anos, em particular a convergência das telecomunicações, a informática e os meios audiovisuais, estão produzindo uma profunda revolução na capacidade social de processar, armazenar e transmitir a informação.

\footnotetext{
${ }^{50}$ FARACO, Alexandre Ditzel. Democracia e regulação das redes eletrônicas de comunicação - rádio, televisão e internet. Belo Horizonte: Editora Fórum, 2009. p. 302.

${ }^{51}$ CUNHA, Paulo Ferreira da. Op. cit., p. 173.
}

Revista de Direito, Estado e Telecomunicações, v. 3, n. 1, p. 205-280 (2011)

DOI: https://doi.org/10.26512/1str.v3i1.21671 
Tradicionalmente ancorados sobre uma base nacional, monotecnológica e frequentemente monopolista, os serviços relacionados à informação estão se modificando rapidamente, ao passo em que se criam autênticos espaços "virtuais", deslocalizados e não hierarquizados, onde "circulam" diariamente milhões de unidades de informação. As consequências econômicas, políticas e culturais desta revolução tecnológica geram enormes desafios para 0 direito. Nenhuma política regulatória nacional pode desconhecer esta realidade variante, potencialmente rica, mas também perturbadora, que desafia os conceitos tradicionais e obriga a uma evolução significativa dos procedimentos e instituições jurídicas. ${ }^{52}$

A título de conclusão, mencione-se ainda que a regulação exercida pelo Estado sobre os institutos e veículos relativos à comunicação deve representar a construção de um regime jurídico adaptado e adaptável às condições requeridas pelo avanço das tecnologias da comunicação, com o intuito de garantir e viabilizar todos os elementos do direito à comunicação: defesa, prestação e participação. Como novamente leciona o professor Lopez-Ayllón, ao cuidar da fundamentalidade do direito à informação:

Finalmente, é necessário enfatizar que a regulamentação da informação não deve significar controlá-la ou dirigi-la. 0 estabelecimento de um marco jurídico deve implicar, ao contrário, a ampliação do regime de garantias, de liberdades e de independência, estabelecendo condições que propiciem a pluralidade, a transparência, e 0 acesso à informação. Em alguns casos, a multiplicação das regras que se mostram superadas pela realidade e pelo avanço tecnológico não é a melhor solução. Trata-se, sobretudo, de uma eleição de caráter político que deve posteriormente traduzir-se em um regime jurídico coerente e criativo que busque fundamentalmente assegurar 0 acesso à informação e sua pluralidade. Esta é, sem dúvida, a melhor garantia do direito à informação. ${ }^{53}$

\section{Sociedade em rede, internet e direito à comunicação}

A partir da construção de um fundamento sólido relativo ao direito fundamental à comunicação, especialmente como um direito à informação de mão dupla, faz-se necessário agora relacionar tal aspecto ao contexto

${ }^{52}$ LOPEZ-AYLLÓN, Sergio. Op. cit., p. 159. Tradução livre.

${ }^{53}$ LOPEZ-AYLLÓN, Sergio. Op. cit., p. 180-181. Tradução livre.

Revista de Direito, Estado e Telecomunicações, v. 3, n. 1, p. 205-280 (2011)

DOI: https://doi.org/10.26512/lstr.v3i1.21671 
atual da sociedade em rede. Essa realidade será abordada a seguir, bem como suas implicações e sua umbilical conexão com a internet.

\section{A sociedade em rede: conceito e implicações}

É usual que se apresente a caracterização da sociedade hodierna como a sociedade do conhecimento ou da informação. Quer-se com isso demonstrar a relevância de tais elementos no contexto do desenvolvimento global, uma vez que este caminho de progresso passa necessariamente pelo avanço tecnológico e pela difusão de conhecimentos especializados e precisos.

Entretanto, pode-se argumentar que conhecimento e informação sempre foram componentes indispensáveis para a sociedade. Sob este ponto de vista, não se poderia diferençar a sociedade atual com base em tal fundamento. Busca-se, então, um aspecto que aperfeiçoe a descrição dessa sociedade em desenvolvimento, que funciona a partir da constante e rápida comunicação.

Assim, o professor Manuel Castells defende a ideia de sociedade em rede para demonstrar que o conhecimento e a informação são hoje “(...) de base microelectrônica, através de redes tecnológicas que fornecem novas capacidades a uma velha forma de organização social: as redes. ${ }^{" 54}$ Com isso, aponta a flexibilidade e a adaptabilidade dessa estrutura, afirmando sua capacidade de descentralizar os mecanismos de decisão.

O mesmo autor expõe os processos que levaram à construção da sociedade em rede. Trata-se da narração da passagem da Galáxia de Gutenberg para Galáxia da Internet:

No final do século XX, três processos independentes se uniram, inaugurando uma nova estrutura social predominantemente baseada em redes: as exigências da economia por flexibilidade administrativa e por globalização do capital, da produção e do comércio; as demandas da sociedade, em que os valores da liberdade individual e da comunicação aberta tornaram-se supremos; e os avanços extraordinários na computação e nas telecomunicações possibilitados pela revolução

${ }^{54}$ CASTELLS, Manuel. A Sociedade em Rede: do Conhecimento à Política. In.: CARDOSO, Gustavo; CASTELLS, Manuel (org.). A sociedade em rede: do conhecimento à acção política. Lisboa: Imprensa Nacional - Casa da Moeda, 2005. Pp. 17.

Revista de Direito, Estado e Telecomunicações, v. 3, n. 1, p. 205-280 (2011)

DOI: https://doi.org/10.26512/1str.v3i1.21671 
microeletrônica. Sob essas condições, a internet, uma tecnologia obscura sem muita aplicação além dos mundos isolados dos cientistas computacionais, dos hackers e das comunidades contraculturais, tornouse a alavanca na transição para uma nova forma de sociedade - a sociedade em rede -, e com ela para uma nova economia. ${ }^{55}$

Assim, percebe-se que diversos fatores contribuíram para a formação da sociedade em rede, dentre eles um movimento da própria sociedade no sentido de obter a concretização de valores de liberdade, bem como o anseio por uma comunicação aberta. Daí o papel indispensável exercido pela internet na esfera das redes, assunto a ser abordado a seguir.

Mostra-se imprescindível compreender como se formam as redes, a fim de se analisarem os elementos primordiais para o funcionamento desse sistema de interconexão que possibilita a construção de uma estrutura de comunicação a partir do compartilhamento de um mesmo código:

Rede é um conjunto de nós interconectados. Nó é o ponto no qual uma curva se entrecorta. (...) A topologia definida por redes determina que a distância (ou intensidade e frequência da interação) entre dois pontos (ou posições sociais) é menor (ou mais frequente, ou mais intensa), se ambos os pontos forem nós de uma rede do que se não pertencerem à mesma rede. (...) Redes são estruturas abertas capazes de expandir de forma ilimitada, integrando novos nós desde que consigam comunicar-se dentro da rede, ou seja, desde que compartilhem os mesmo códigos de comunicação (por exemplo, valores ou objetivos de desempenho). ${ }^{56}$

Então, com base em um sistema de comunicação compartilhado, tem-se que é possível estabelecer uma conexão entre dois ou mais pontos, de modo que estes consigam se comunicar de modo mais rápido, em face do encurtamento da distância. Além disso, esse modelo permite uma expansão

${ }^{55}$ CASTELLS, Manuel. A Galáxia da Internet: reflexões sobre a Internet, os negócios e a sociedade. Trad. Maria Luiza X. de A. Borges. Rio de Janeiro: Jorge Zahar, 2003. p. 8.

${ }^{56}$ CASTELLS, Manuel. A Sociedade em Rede - A era da informação: economia, sociedade e cultura. Vol. 1. Trad. Roneide Venâncio Majer. São Paulo: Paz e Terra, 1999. p. 498. 
ilimitada das redes, que são construídas mediante a integração de novos nós que "falem" a mesma linguagem. ${ }^{57}$

Todavia, o conceito de sociedade em rede vai mais além, traduzindo a noção de globalização de modo mais analítico, enfatizando a comunicação sem fronteiras como manifestação das relações transnacionais. "Então, a sua lógica chega a países de todo o planeta e difunde-se através do poder integrado nas redes globais de capital, bens, serviços, comunicação, informação, ciência e tecnologia." 58

Em consequência, todos os setores da vida humana são transformados, a partir do estabelecimento de um quadro de difusão das redes como modelo operacional: "Redes constituem a nova morfologia social de nossas sociedades, e a difusão da lógica de redes modifica de forma substancial a operação e os resultados dos processos produtivos e de experiência, poder e cultura." ${ }^{59}$

${ }^{57}$ Sobre o encurtamento das distâncias possibilitado pelas tecnologias de telecomunicações e a relevância dessa evolução para os países em desenvolvimento, Hudson, em 1993, já dizia: "Telecomunicações constituem um 'conector faltante' em boa parte do mundo em desenvolvimento (...) O conector das telecomunicações não é apenas uma conexão entre pessoas, mas um elo da corrente do próprio processo de desenvolvimento. (...) Distância representa tempo, em um mundo cada vez mais consciente da importância do tempo. Em economias que dependem muito da agricultura ou do extrativismo (madeira e minerais), a distância entre mercados urbanos foi tradicionalmente aliviada apenas pela instalação de melhorias de transporte, tipicamente estradas. Ainda assim, as conexões de transporte mantêm as indústrias sem o acesso a informações que são cada vez mais importantes para a produção e comercialização de suas commodities. HUDSON, Heather E. Maximizing Benefits from New Telecommunications Technologies: Policy Challenges for Developing Countries. In.: JUSSAWALLA, Meheroo (Ed.). Global telecommunications policies: the challenge of change. Wesport: Greenwood Press, 1993. p. 207. Tradução livre.

${ }^{58}$ CASTELLS, Manuel. A Sociedade em Rede: do Conhecimento à Política. In: CARDOSO, Gustavo; CASTELLS, Manuel (org.). A sociedade em rede: do conhecimento à acção política. Lisboa: Imprensa Nacional, 2005. p. 18.

${ }^{59}$ CASTELLS, Manuel. A Sociedade em Rede - A era da informação: economia, sociedade e cultura. Vol. 1. Trad. Roneide Venâncio Majer. São Paulo: Paz e Terra, 1999. p. 497.

Revista de Direito, Estado e Telecomunicações, v. 3, n. 1, p. 205-280 (2011)

DOI: https://doi.org/10.26512/1str.v3i1.21671 
Tem-se, assim, que a sociedade em rede representa verdadeira reorganização da sociedade, ou seja, proporciona um rearranjo das relações estabelecidas entre indivíduos e grupos, não apenas quanto às possibilidades de comunicação que se estabelecem, mas também em relação a novas formas de trabalho, de funcionamento de mercados e mesmo de intervenções políticas.

A questão é que, apesar desse alcance profundo e global, a sociedade em rede não inclui todas as pessoas. Apesar de todos serem afetados pelas relações e organizações dela decorrentes, a maioria da população mundial ainda está excluída do processo emanado dessa nova lógica social.

Especificamente quanto à comunicação na sociedade em rede, o sistema funciona de forma a evidenciar as diferenças entre os países e as desigualdades mesmo dentro das nações, em um contexto de pobreza digital e limitação da participação da sociedade nos processos de tomada de decisão e de troca de conhecimentos. Daí que o professor Ingo Sarlet, baseando-se no aclamado historiador Eric Hobsbawm, explica que:

No que diz com os reflexos para a problemática da efetivação dos direitos fundamentais, o abismo da diferença econômica não se refere apenas à divisão entre países desenvolvidos e subdesenvolvidos, mas também às gritantes diferenças econômicas entre as classes alta e baixa, como resultado da injusta distribuição de renda no âmbito da economia interna dos países em desenvolvimento. ${ }^{60}$

Obviamente, esse abismo de que cuida Hobsbawm não se refere apenas ao acesso aos meios de comunicação e aos conhecimentos necessários à inserção do indivíduo na sociedade globalizada, mas também principalmente nos países subdesenvolvidos ou em desenvolvimento - às necessidades básicas de sobrevivência digna da pessoa humana. A preocupação, porém, neste momento, é indagar de que forma essas desigualdades manifestam-se quanto às possibilidades de participação dos cidadãos nos processos de comunicação e desenvolvimento do país.

Assim, quanto ao ponto, Castells ensina que é imprescindível não apenas proporcionar o acesso das pessoas aos meios de comunicação, processo hoje

${ }^{60}$ SARLET, Ingo Wolfgang. A eficácia dos direitos fundamentais. $9^{\mathrm{a}}$ ed., Porto Alegre: Livraria do Advogado, 2007. p. 25.

Revista de Direito, Estado e Telecomunicações, v. 3, n. 1, p. 205-280 (2011) 
conhecido como inclusão digital, mas sobretudo garantir a efetiva condição de participação do indivíduo dentro desse processo de comunicação, com todas as possibilidades que lhe são inerentes. ${ }^{61}$

Vê-se, portanto, que a discussão proposta diz respeito às necessidades que emergem dessa realidade de um mundo que, cada vez mais, busca estabelecer relações e conexões que permitam maior velocidade no tráfego de informações e dados, a fim de auxiliar e impulsionar o crescimento econômico segundo a ótica do capitalismo informacional. Neste momento, é preciso ressaltar as palavras de Castells, em relação ao envolvimento das pessoas no mecanismo da economia informacional e sua lógica:

Portanto, embora a economia informacional afete 0 mundo inteiro e, nesse sentido, seja global mesmo, a maior parte das pessoas do planeta não trabalha para a economia informacional global nem compra seus produtos. Entretanto, todos os processos econômicos e sociais relacionam-se à lógica da estrutura dominante nessa economia. ${ }^{62}$

Há, porém, uma barreira a ser vencida, que é exatamente o questionamento levantado pelo professor Castells. É que essa estrutura de uma sociedade em rede só faz sentido, em termos de avanço e desenvolvimento sociais, caso seja superada a distância que há entre a ausência de compreensão exata, por parte das pessoas de um modo geral, das implicações de uma estrutura desse tipo, de um lado, e as reais possibilidades decorrentes do modelo, de outro. ${ }^{63} \mathrm{O}$ ilustre autor explica:

${ }^{61}$ CASTELLS, Manuel. A Sociedade em Rede: do Conhecimento à Política. In: CARDOSO, Gustavo; CASTELLS, Manuel (org.). A sociedade em rede: do conhecimento à acção política. Lisboa: Imprensa Nacional, 2005. p. 19 ${ }^{62}$ CASTELLS, Manuel. A Sociedade em Rede - A era da informação: economia, sociedade e cultura. Vol. 1. Trad. Roneide Venâncio Majer. São Paulo: Paz e Terra, 1999. p. 120.

${ }^{63}$ Para a superação desses desafios, faz-se necessária uma política pública de investimento e desenvolvimento que considere as peculiaridades nacionais, a fim de se optar por meios e ferramentas adequados às necessidades verificadas. É o que explica Jussawalla: "A maior vantagem da revolução das telecomunicações é que diferentes países e seus administradores têm diante de si uma grande variedade de opções de equipamentos, processos e serviços a partir dos quais podem encontrar os sistemas mais adequados às necessidades nacionais. A seleção geralmente depende Revista de Direito, Estado e Telecomunicações, v. 3, n. 1, p. 205-280 (2011) 
"Existe de facto um grande hiato entre conhecimento e consciência pública, mediada pelo sistema de comunicação e pelo processamento de informação dentro das nossas «molduras» mentais." 64

As crises geradas por esse hiato enxergado por Castells serão retomadas posteriormente. Agora, no entanto, é necessário compreender com clareza o que se entende por sociedade em rede, a fim de se afastarem eventuais imprecisões relativas às diversas aplicações desta expressão. O professor Manuel Castells define sociedade em rede do seguinte modo:

A sociedade em rede, em termos simples, é uma estrutura social baseada em redes operadas por tecnologias de comunicação e informação fundamentadas na microelectrónica e em redes digitais de computadores que geram, processam e distribuem informação a partir de conhecimento acumulado nos nós dessas redes. ${ }^{65}$

Ora, à luz desse conceito é possível verificar que as redes são uma manifestação do desenvolvimento tecnológico, que permite, entre outras coisas, uma comunicação altamente eficiente e veloz, imprescindível no contexto da economia globalizada.

Daí que uma faceta da sociedade em rede é a própria economia em rede, pois os alicerces da produção dos países são alterados na medida em que sua organização tecno-econômica evolui dentro do contexto das redes.

Yochai Benkler, em The wealth of networks, demonstra a essencialidade da informação para o desenvolvimento. Além disso, revela as transformações pelas quais a economia e a sociedade necessariamente passam, em face do exercício das autonomias individuais e da atuação dos

de fatores políticos, econômicos e sociológicos, mas o objetivo da política de investimento em cada país é obter o máximo bem-estar a custo mínimo, sujeito a limitações de tecnologia disponível, recursos, imperfeições de mercado e embaraços institucionais." (JUSSAWALA, Meheroo. Challenge of Change. In.: JUSSAWALLA, Meheroo. Global Telecommunications Policies: The Challenge of Change. Wesport: Greenwood Press, 1993. p. 243-244. Tradução livre). ${ }^{64}$ CASTELLS, Manuel. A Sociedade em Rede: do Conhecimento à Política. In: CARDOSO, Gustavo; CASTELLS, Manuel (org.). A sociedade em rede: do conhecimento à acção política. Lisboa: Imprensa Nacional, 2005. p. 20. ${ }^{65}$ CASTELLS, Manuel. Op. cit., p. 20. 
grupos sociais, notadamente a partir da revolução causada pela internet. Nas palavras de Benkler:

Informação, conhecimento e cultura são centrais para a liberdade e 0 desenvolvimento humanos. 0 modo pelo qual eles são produzidos e compartilhados em nossa sociedade afeta criticamente nossa visão acerca do estado do mundo, como é e como poderia ser; quem decide essas questões; e como nós, quanto às sociedades e políticas, compreendemos o que pode e deve ser feito. Por mais de 150 anos, democracias modernas complexas dependerão em grande medida de uma economia industrial da informação para essas funções básicas. Na última década e meia, nós começamos a ver uma mudança radical na organização da produção de informação. Possibilitada pelo avanço tecnológico, estamos começando a enxergar uma série de adaptações econômicas, sociais e culturais que torna possível uma transformação radical no modo pelo qual nós construímos o ambiente informacional que ocupamos como indivíduos autônomos, cidadãos e membros de grupos culturais e sociais. Parece ultrapassado falar hoje na "revolução da internet". Em alguns círculos acadêmicos, é possivelmente ingênuo. Entretanto, não deveria ser. A mudança ocasionada pelo ambiente informacional em rede é profunda. É estrutural. Ela alcança os fundamentos de como os mercados e as democracias liberais co-evoluíram por quase dois séculos. ${ }^{66}$

Vê-se que as relações sociais são profundamente alteradas e essas modificações passam pelas redes como instrumentos de interligação entre as pessoas, gerando o que Castells denomina como uma "sociedade hipersocial". É que as possibilidades de comunicação e troca de informações são tantas que é criada uma estrutura mista entre o real e o virtual, produzindo-se uma "sociedade de indivíduos em rede." ${ }^{\prime 67}$

Finalmente, Castells faz referência específica às transformações provocadas pela sociedade em rede na própria comunicação. É aí o ponto central que se quer abordar no bojo desta indagação acerca da

${ }^{66}$ BENKLER, Yochai. The Wealth of Networks: How Social Production Transforms Markets and Freedom. New Haven and London: Yale University Press, 2006. p. 1. Tradução livre.

${ }^{67}$ CASTELLS, Manuel. Op. cit., p. 23.

Revista de Direito, Estado e Telecomunicações, v. 3, n. 1, p. 205-280 (2011)

DOI: https://doi.org/10.26512/lstr.v3i1.21671 
fundamentalidade do direito à comunicação, manifestado pelo acesso à internet, dentro do contexto da sociedade em rede.

Segundo Castells, "a comunicação constitui o espaço público, ou seja, o espaço cognitivo em que as mentes das pessoas recebem informação e formam os seus pontos de vista através do processamento de sinais da sociedade no seu conjunto." ${ }^{\prime 68}$ Esse espaço público de comunicação é marcado pelo que se abordará em seguida como um direito à informação de mão dupla, a partir do qual as pessoas emitem e recebem informações constantemente, exercendo suas liberdades em um ambiente tecnológico diverso e plural.

Não há como deixar de citar as tendências elencadas por Castells em face dessa nova comunicação existente na sociedade em rede:

- A comunicação é, em grande medida, organizada em torno dos negócios de mídia aglomerados que são globais e locais simultaneamente, e que incluem a televisão, a rádio, a imprensa escrita, a produção audiovisual, a publicação editorial, a indústria discográfica e a distribuição, e as empresas comerciais on-line. Estes aglomerados estão ligados às empresas de mídia em todo o mundo, sob diferentes formas de parceria, enquanto se envolvem, a mesmo tempo, em ferozes competições. A comunicação é simultaneamente global e local, genérica e especializada, dependente de mercados e de produtos.

- O sistema de comunicação está cada vez mais digitalizado e gradualmente mais interactivo. A concentração do negócio, não significa que exista um processo comunicativo unificado e unidireccional. As sociedades têm vindo a movimentar-se de um sistema de mass media para um sistema multimídia especializado e fragmentado, em que as audiências são cada vez mais segmentadas. Como o sistema é diversificado e flexível, é cada vez mais inclusivo de todas as mensagens enviadas na sociedade. Por outras palavras, a maleabilidade tecnológica dos novas mídias permite uma muito maior integração de todas as fontes de comunicação no mesmo hipertexto. Logo, a comunicação digital tornou-se menos organizada centralmente, mas absorve, na sua lógica, uma parte crescente da comunicação social.

- Com a difusão da sociedade em rede e com a expansão das redes de novas tecnologias de comunicação, dá-se uma explosão de redes

${ }^{68}$ CASTELLS, Manuel. Idem.

Revista de Direito, Estado e Telecomunicações, v. 3, n. 1, p. 205-280 (2011) 
horizontais de comunicação, bastante independentes do negócio das mídias e dos governos, o que permite a emergência daquilo a que chamei comunicação de massa autocomandada. É comunicação de massas porque é difundida em toda a internet, podendo potencialmente chegar a todo o planeta. É autocomandada porque geralmente é iniciada por indivíduos ou grupos, por eles próprios, sem a mediação do sistema de mídias. A explosão de blogues, vlogues (vídeo-blogues), podding, streaming e outras formas de interactividade. A comunicação entre computadores criou um novo sistema de redes de comunicação global e horizontal que, pela primeira vez na história, permite que as pessoas comuniquem umas com as outras sem utilizar os canais criados pelas instituições da sociedade para a comunicação socializante. ${ }^{69}$

Dentre essas tendências, é preciso referir-se especialmente à existência de um sistema de comunicação global horizontal. Isso significa que as pessoas podem se comunicar de modo eficiente e direto umas com as outras, num canal de mão dupla em que o fluxo de informação ocorre sem interferências diretas por parte de instituições sociais, ao menos potencialmente.

Esse é o fato marcante para o estudo proposto: a verificação de que hoje é possível estabelecer uma comunicação mais livre e rápida, que insira as pessoas em um contexto de cidadania mais efetiva e participativa, mediante a obtenção e a produção pessoal de informação de todo tipo.

As consequências dessa realidade são incalculáveis, mas é imprescindível ressaltar que, entendido o direito à comunicação como um direito fundamental, necessário para concretizar a dignidade da pessoa humana e apto a capacitar as pessoas a lidarem com o mundo globalizado estruturado em redes, é necessário projetar de que modo, em um país em desenvolvimento como o Brasil, é possível expandir essas potencialidades a toda a população.

A interatividade decorrente da estrutura das redes e a realidade de difusão do conhecimento tecnológico pelo planeta produzem uma situação impressionante de difusão do conhecimento e das possibilidades de produção cultural e científica, ponto bem destacado por Yochai Benkler em palestra proferida em Oxford, Inglaterra, em julho de 2005:

${ }^{69}$ CASTELLS, Manuel. Op. cit., p. 23-24.

Revista de Direito, Estado e Telecomunicações, v. 3, n. 1, p. 205-280 (2011)

DOI: https://doi.org/10.26512/1str.v3i1.21671 
(...) as capacidades de computação, armazenamento comunicações estão nas mãos de praticamente todas as pessoas conectadas - e esses são os capitais físicos básicos necessários para a produção de informação, conhecimento e cultura, nas mãos de aproximadamente 600 milhões a um bilhão de pessoas no planeta. ${ }^{70}$

Assim, percebe-se que hoje, mais do que em qualquer outro momento da história, as pessoas podem ter acesso, mediante a comunicação estabelecida pelas redes, a todo tipo de informação que desejarem. Aliás, não apenas isso, mas podem elas mesmas produzir e difundir suas próprias criações, em uma velocidade antes impensável, em um espaço potencialmente sem fronteiras.

Inevitavelmente, essa liberdade sofre restrições e é limitada, de um lado, por disfunções de mercado, e, de outro, pelas conjunturas dos países, em especial daqueles subdesenvolvidos ou em desenvolvimento. No caso destes, há que se lidar com circunstâncias sociais e econômicas que inibem essa difusão de conhecimento, informação e cultura de forma livre.

O Estado também sofre transformações no contexto dessa sociedade em rede, uma vez que a própria soberania nacional é afetada pelo mundo globalizado, que tende a não se limitar a fronteiras geográficas e requer condutas ágeis - que, por sua vez, dependem de informação e tecnologia.

Castells explica: "Como a sociedade em rede é global, o Estado da sociedade em rede não pode funcionar única ou primeiramente no contexto nacional. Está comprometido num processo de governança global, mas sem um governo global."71

A integração regional e a proliferação de organizações internacionais são marcas desse processo, que inclui ainda a constatação de que a sociedade em rede não é mais apenas uma tendência ou uma previsão, mas uma realidade, instituída em maior ou menor grau nos países, a partir da qual devem ser construídas as políticas e estratégias de desenvolvimento.

\footnotetext{
${ }^{70}$ BENKLER, Yochai. Open-source economics: Yochai Benkler on TED.com. Palestra proferida em Oxford, Inglaterra, em julho de 2005. Vídeo disponível em http://blog.ted.com/2008/04/yochai_benkler_1.php (acesso em 07 de agosto de 2009). Tradução livre.
}

${ }^{71}$ CASTELLS, Manuel. Op. cit., p. 25. 


\section{A essencialidade da internet na sociedade em rede}

Dentro dessa realidade da sociedade em rede e das transformações pelas quais passa a comunicação em face do contexto atual, a internet emerge como o principal protagonista do processo de reconstrução da estrutura social.

É que se trata de uma ferramenta muitíssimo poderosa, que, se utilizada com esse propósito, é capaz de auxiliar a construção de um novo projeto de sociedade, pautada na eficiência da comunicação e, oxalá, na participação democrática dos cidadãos.

A internet tem sua origem vinculada a diversos estudos científicos de cunho eminentemente militar, que tiveram início na década de 1960, em especial nos Estados Unidos. Contudo, sua real inserção na vida cotidiana da sociedade em geral deu-se por volta de 1995. Trata-se, portanto, de um fenômeno muito recente, conquanto sua importância na atual conjuntura socioeconômica seja tremenda. ${ }^{72}$

Castells demonstra que a internet já se tornou de tal forma indispensável que constitui a base tecnológica capaz de permitir a organização da sociedade a partir das redes, no contexto da Era da Informação, equivalendo, desse modo, ao que representava a eletricidade na Era Industrial. ${ }^{73}$

Obviamente, a ampliação do acesso à internet e das possibilidades dela decorrentes evoluem de forma diferenciada nos países e mesmo dentro de um país. Assim, Gustavo Cardoso analisa, a partir de estatísticas recentes, a centralidade da internet na transição das sociedades para a sociedade em rede. Explica o autor que a definição desse protagonismo depende do uso que se faz da tecnologia a ela associada:

Nessa perspectiva, a autonomização dos indivíduos e grupos é seguida pela sua tentativa de reconstruir sentido, numa nova estrutura social, a partir dos seus projectos auto-definidos. A internet, em conjugação com os mass media, ao fornecer os meios tecnológicos para a socialização do

\footnotetext{
${ }^{72}$ CASTELLS, Manuel. A Galáxia da Internet: reflexões sobre a Internet, os negócios e a sociedade. Trad. Maria Luiza X. de A. Borges. Rio de Janeiro: Jorge Zahar, 2003. p. 19.

${ }^{73}$ CASTELLS, Manuel. A Sociedade em Rede - A era da informação: economia, sociedade e cultura. Vol. 1, trad. Roneide Venâncio Majer. São Paulo: Paz e Terra, 1999. p. 7.
}

Revista de Direito, Estado e Telecomunicações, v. 3, n. 1, p. 205-280 (2011)

DOI: https://doi.org/10.26512/1str.v3i1.21671 
projecto de cada um numa rede de sujeitos similares, torna-se uma poderosa ferramenta de reconstrução social e não um pretexto para a desintegração. Mas essa (re)construção social não terá de seguir a mesma lógica dos valores da sociedade industrial tardia, de onde emerge a nova estrutura. ${ }^{74}$

Em verdade, sua observação origina-se do entendimento de que a evolução mundialmente experimentada, aqui denominada transição para a sociedade em rede, pode ser comparada ao ingresso dos países na Era Industrial, que ocorreu em momentos diversos nas nações, a depender do poderio econômico e do domínio das novas tecnologias.

Semelhantemente, os países ingressam com maior ou menor velocidade na sociedade em rede, em razão de diversos fatores que os singularizam, em termos políticos, técnicos e competitivos, dentre outros fatores, no mundo globalizado.

O destaque a se fazer, quanto ao ponto, é que a internet tornou-se uma ferramenta poderosa para a reconstrução social, independentemente de o novo modelo seguir ou não os passos verificados na história da sociedade industrial. E a lógica dessa reconstrução encontra-se aberta e indefinida, ou seja, passível de determinação por seus agentes.

A internet assume papel de destaque nessa transição pelas possibilidades que lhe são inerentes, apesar de nem sempre os usuários aperceberem-se dessa realidade. Percebe-se, então, que há países já imersos nesta nova fase da evolução social, cujas sociedades estão altamente envolvidas com as tecnologias e, em particular, fazem uso da internet de modo constante, para fins pessoais e profissionais.

Há que se ressaltar, porém, o fato de que muitos países encontram-se ainda em transição para esse modelo. Nesses locais, é marcante e significativa a divisão entre quem usa e quem não usa as novas tecnologias, como a internet. ${ }^{75}$

Além do mero acesso, porém, há que se atentar sobretudo para a qualidade do acesso - velocidade e largura da banda -, fator determinante

${ }^{74}$ CARDOSO, Gustavo. Sociedades em transição para a sociedade em rede. In: CARDOSO, Gustavo; CASTELLS, Manuel (org.). A sociedade em rede: do conhecimento à acção política. Lisboa: Imprensa Nacional, 2005. p. 31.

${ }^{75}$ CARDOSO, Gustavo. Op. cit., p. 32.

Revista de Direito, Estado e Telecomunicações, v. 3, n. 1, p. 205-280 (2011) 
para o efetivo incremento na qualidade das comunicações e para a real transformação prometida pelo advento da internet, sob pena de os serviços e programas a ela vinculados e desenvolvidos com o objetivo de aprimorar o trabalho e a comunicação serem limitados ou mesmo inviabilizados. ${ }^{76}$

Note-se o aviso dado por Castells quanto à possibilidade de que o próprio uso da internet cause uma acentuação das diferenças existentes entre poderosos e os marginalizados, quando expõe, com a maestria habitual, que "A internet é de fato uma tecnologia da liberdade - mas pode libertar os poderosos para oprimir os desinformados, pode levar à exclusão dos desvalorizados pelos conquistadores do valor." 77

A cultura de liberdade verificada no ambiente online decorre, em grande medida, da própria origem da internet, que, conquanto imaginada inicialmente no ambiente militar, foi desenvolvida numa cultura estudantil de liberdade e libertação, como instrumento de livre comunicação e de ferramenta para a absorção de um poder de informação à margem dos governos e das corporações. ${ }^{78}$ Portanto, "A internet é, acima de tudo, uma criação cultural." $" 79$

Sendo assim, as possibilidades de impacto sobre a cultura e a sociedade de forma geral são enormes. ${ }^{80}$ Isso porque a internet gera um ambiente

${ }^{76}$ CASTELLS, Manuel. A Galáxia da Internet: reflexões sobre a Internet, os negócios e a sociedade. Trad. Maria Luiza X. de A. Borges. Rio de Janeiro: Jorge Zahar, 2003. p. 210.

${ }^{77}$ CASTELLS, Manuel. Op. cit., p. 225.

${ }^{78}$ CASTELLS, Manuel. Op. cit., p. 26.

${ }^{79}$ CASTELLS, Manuel. Op. cit., p. 32.

${ }^{80} \mathrm{Em}$ 1992, Akwule analisava a passagem para uma sociedade pós-industrial ou informacional nos seguintes termos: "De acordo com a história, a corrente transformação em uma sociedade baseada na informação conecta-se às inovações tecnológicas da época, especialmente aquelas que combinam telecomunicações e tecnologias de computação. Mais cedo na história, o surgimento de tecnologias de caça produziu uma era de existência humana baseada na caça. Similarmente, o advento da agricultura e, posteriormente, da manufatura conduziu à transição, de início, para a sociedade agrícola e, em seguida, para a industrial. Agora, os avanços nas telecomunicações ocupam o papel central da evolução da sociedade na era da informação. Este conceito é relevante para todos, mesmo para as sociedades mais pobres do mundo, muitas das quais sequer fizeram suas transições da sociedade Revista de Direito, Estado e Telecomunicações, v. 3, n. 1, p. 205-280 (2011) 
digital de compartilhamento de valores, que, sob certo aspecto, substitui a própria geografia das relações sociais:

Os processos de transformação social sintetizados no tipo ideal de sociedade em rede ultrapassam a esfera de relações sociais e técnicas de produção: afetam a cultura e o poder de forma profunda. As expressões culturais são retiradas da história e da geografia e tornam-se predominantemente mediadas pelas redes de comunicação eletrônica que interagem com o público e por meio dele em uma diversidade de códigos e valores, por fim incluídos em um hipertexto audiovisual digitalizado. ${ }^{81}$

Sob outro aspecto, também decorre da consolidação da internet como tecnologia e ferramenta básica da sociedade em rede o fato de que, nessa fase ainda inicial do seu desenvolvimento, “(..) a volatilidade, a insegurança, a desigualdade e a exclusão social andam de mãos dadas com a criatividade, a inovação, a produtividade e a criação de riqueza nesses primeiros passos do mundo baseado na internet." 82 Por isso, é comum haver dúvidas e incertezas em relação aos reais benefícios e progressos a serem obtidos mediante tal instrumento.

Todavia, parece inegável que, no mundo de hoje, o desenvolvimento passa, necessariamente, pelo uso da internet. A grande crise, porém, é justamente em relação às diferentes formas pelas quais o acesso se difunde no espaço, principalmente quanto à separação existente entre os países desenvolvidos e subdesenvolvidos.

As respostas a esse desafio afetam significativamente as possibilidades de se vislumbrar a redução dessa distância. Daí a necessidade de se buscar um mecanismo de amenização do desequilíbrio, uma vez constatado o fato

agrícola para a industrial. O conceito de uma sociedade global, informacional e eletrônica enfatiza a extraordinária importância da informação como commodity." (AKWULE, Raymond. Global Telecommunications: The Technology, Administration, and Policies. Boston: Focal Press, 1992. p. 1. Tradução livre). ${ }^{81}$ CASTELLS, Manuel. A Sociedade em Rede - A era da informação: economia, sociedade e cultura. Vol. 1. Trad. Roneide Venâncio Majer. São Paulo: Paz e Terra, 1999. p. 504.

${ }^{82}$ CASTELLS, Manuel. A Galáxia da Internet: reflexões sobre a Internet, os negócios e a sociedade. Trad. Maria Luiza X. de A. Borges. Rio de Janeiro: Jorge Zahar Ed., 2003. p. 9. 
de que "o uso da internet está se difundindo rapidamente, mas essa difusão segue um padrão espacial que fragmenta sua geografia segundo riqueza, tecnologia e poder: é a nova geografia do desenvolvimento." ${ }^{83}$

\section{Direito à comunicação como um direito à informação de mão dupla e a internet}

Como se viu no capítulo anterior, costuma-se identificar a fundamentalidade do direito à informação com certa tranquilidade. Trata-se, essencialmente, de um direito fundamental de cunho negativo, que tem por finalidade primordial proteger o cidadão, titular do direito, de eventuais censuras ou restrições impostas pelo Estado ao exercício dessa liberdade.

Nota-se, desse modo, que, sob tal ponto de vista, o direito à informação é encarado como um direito de mão única, ou seja, um direito que assegura ao seu titular o acesso às informações que lhe sejam colocadas à disposição pelos veículos de comunicação e pelos demais agentes sociais. Entretanto, parece insuficiente essa abordagem diante das possibilidades que emergem do avanço das (tele)comunicações, bem como em face da organização da sociedade em rede.

É que as redes permitem um grau de interação anteriormente impensável entre os indivíduos conectados, não apenas no sentido de obtenção de dados e informação, mas numa realidade de trocas constantes e de produção de informação e conhecimento, como se percebeu nos tópicos anteriores deste capítulo.

Daí que se torna necessário conceber, com maior pertinência, um direito fundamental à comunicação, conceito este que permite falar-se em um tradicional direito à informação, porém qualificado como de mão dupla, como já referido anteriormente, e não mais uma mera garantia de não censura.

O Relatório MacBride (UNESCO, 1980) indicou esse caminho, ao preconizar que:

As necessidades de comunicação em uma sociedade democrática devem ser atingidas por meio da extensão de direitos específicos, tais como 0 direito de ser informado, o direito de informar, o direito à privacidade, 0

${ }^{83}$ CASTELLS, Manuel. Op. cit., p. 174.

Revista de Direito, Estado e Telecomunicações, v. 3, n. 1, p. 205-280 (2011)

DOI: https://doi.org/10.26512/1str.v3i1.21671 
direito a participar na comunicação pública, todos eles elementos de um novo conceito, o direito de comunicar. ${ }^{84}$

Sobre a transição para a extensão desses direitos específicos, de que cuida o referido relatório, Wimmer explica:

Embora os direitos à comunicação estejam diretamente relacionados ao direito de informação e às liberdades de expressão e de imprensa, assumem abrangência mais ampla: não se trata, simplesmente, de defender um livre fluxo de informação unidirecional, mas de sustentar 0 direito a um processo bidirecional de comunicação, cujos participantes possam manter um diálogo democrático e equilibrado. ${ }^{85}$

Assim, vê-se o maior alcance desse direito à comunicação em relação ao direito à informação e a necessidade de se qualificar esse direito à comunicação como fundamental, a fim de que as oportunidades decorrentes da estrutura das redes e do avanço das tecnologias de comunicação sejam aproveitadas, principalmente no sentido de gerar inclusão e desenvolvimento.

Lembre-se, quanto à internet - ferramenta central no processo de efetivação do direito à comunicação -, de que suas origens - muitas delas encontradas na cultura hacker das universidades norte-americanas refletem o conceito de liberdade e de interação que pautaram seu desenvolvimento:

(...) o que é comum à cultura hacker, em todos os contextos sociais, é a premência de reiventar maneiras de se comunicar com computadores e por meio deles, construindo um sistema simbiótico de pessoas e computadores em interação na internet. A cultura hacker é, em essência, uma cultura de convergência entre seres humanos e suas máquinas num processo de interação liberta. É uma cultura de criatividade intelectual

${ }^{84}$ UNESCO. Many Voices One World. London: Kogan Page, 1980. Disponível em http://unesdoc.unesco.org (acesso em 23 de setembro de 2009). Tradução livre. p. 265.

${ }^{85}$ WIMMER, Miriam. O direito à comunicação na Constituição de 1988: o que existe e o que falta concretizar. In: Eco-Pós (UFRJ), v. 11, p. 146-165, 2008. p. 147. 
fundada na liberdade, na cooperação, na reciprocidade e na informalidade. ${ }^{86}$

Essa reinvenção das maneiras de se comunicar vista no decorrer da evolução da internet é a marca da sociedade em rede. As transformações alcançam, porém, todas as esferas sociais, e não somente a troca de informações simples entre indivíduos. Há um sentido de cooperação, ainda que inconsciente, decorrente do exercício da liberdade de comunicar, que acarreta consequências positivas para a vida em coletividade.

Yochai Benkler analisa o fato sob a perspectiva de que são produzidos efeitos coordenados a partir dos esforços individuais de comunicação nas redes, e a soma desses esforços origina um ambiente de informação totalmente diverso e rico:

0 fato de que cada esforço está disponível a qualquer pessoa de qualquer lugar conectada a uma rede conduziu ao surgimento de uma coordenação de efeitos, na qual os efeitos das ações individuais, uma vez agregados ainda que sem uma consciência individual de cooperação - produzem 0 efeito coordenado de um novo e rico ambiente informacional. ${ }^{87}$

O resultado descrito por Benkler aponta para um caminho de desenvolvimento desejável, uma vez que é construído pelos próprios agentes, no exercício de suas liberdades de manifestarem e produzirem conhecimento e informação, bem como de se utilizarem do compartilhamento de experiências de outros para agregarem conceitos e valores às suas próprias.

A internet permite que esses efeitos sejam materializados, pois representa um espaço de liberdade e interação, cuja eficiência é sem precedentes. Tem-se, assim, que o espaço de liberdade encontrado na web deve ser potencializado de modo a produzir democratização e igualdade de oportunidades, a fim de que os indivíduos participem ativamente dos processos decisórios e contribuam, de fato, para o desenvolvimento.

${ }^{86}$ CASTELLS, Manuel. Op. cit., p. 45.

${ }^{87}$ BENKLER, Yochai. The Wealth of Networks: How Social Production Transforms Markets and Freedom. New Haven and London: Yale University Press, 2006. p. 4-5. Tradução livre.

Revista de Direito, Estado e Telecomunicações, v. 3, n. 1, p. 205-280 (2011)

DOI: https://doi.org/10.26512/1str.v3i1.21671 
O capital necessário para a produção, na era do informacionalismo, torna-se descentralizado e disperso, ao contrário do que parecia ocorrer no industrialismo, em que os meios de produção se concentravam nas mãos dos industriais, limitando-se, em grande medida, as possibilidades de acesso das classes operárias ao conhecimento sobre o modo de geração de riqueza.

Daí a extrema relevância do ensino de Benkler, ao explicar o funcionamento da economia informacional de redes, baseada justamente na pluralidade e fluidez dos capitais de produção de informação e conhecimento:

$\mathrm{Na}$ economia informacional em rede, o capital físico necessário para a produção está largamente distribuído pela sociedade. Computadores pessoais e conexões de rede são onipresentes. Isso não significa que não podem ser usados para os mercados, ou que os indivíduos cessam de procurar oportunidades de mercado. Significa, contudo, que sempre que alguém, em algum lugar, entre o bilhão de seres humanos conectados e finalmente entre todos aqueles que estarão conectados, deseja criar algo que precise de criatividade humana, um computador e uma conexão de rede, ele ou ela pode fazer, sozinho ou em cooperação com outros. Ele ou ela já tem a capacidade de capital necessária para fazê-lo. Se não por si só, então ao menos em cooperação com outros indivíduos, atuando por razões complementares. $\mathrm{O}$ resultado é que bons negócios, quanto aos parâmetros de valor humanos, podem ser feitos diretamente por indivíduos que interagem entre si, em vez de os fazerem enquanto atores de mercado, mediante 0 sistema de preços. ${ }^{88}$

Ressalte-se, finalmente, que o enfrentamento das liberdades e da autonomia decorrentes da internet é descrito por Castells:

Na verdade, a liberdade nunca é uma dádiva. É uma luta constante; é a capacidade de redefinir autonomia e pôr a democracia em prática em cada contexto social e tecnológico. A internet encerra um potencial extraordinário para a expressão dos direitos dos cidadãos e a comunicação de valores humanos. Certamente não pode substituir a mudança social ou a reforma política. Contudo, ao nivelar relativamente o terreno da manipulação simbólica, e ao ampliar as fontes de comunicação, contribui de fato para a democratização. A internet põe as

${ }^{88}$ BENKLER, Yochai. Op. cit., p. 6. Tradução livre.

Revista de Direito, Estado e Telecomunicações, v. 3, n. 1, p. 205-280 (2011) 
pessoas em contato numa ágora pública, para expressar suas inquietações e partilhar suas esperanças. É por isso que o controle dessa ágora pública pelo povo talvez seja a questão política mais fundamental suscitada pelo seu desenvolvimento. ${ }^{89}$

Conclui-se, portanto, que a circunstância de uma pessoa, munida de um computador, ou até mesmo de um telefone celular, poder interferir na realidade e produzir conhecimento e informação, bem como acessar produções de terceiros e dialogar com estes, em um processo de mão dupla, delineia um quadro de infinitas pontes de cooperação e oportunidades de crescimento individual e coletivo.

A partir dessas constatações, buscar-se-á, em seguida, analisar a gênese da preocupação de se garantir e viabilizar o acesso à internet no Brasil, como consequência da nova realidade global de transição para a sociedade em rede e da essencialidade da internet nesse processo de difusão do conhecimento e da informação, que atinge todas as áreas da vida social.

\section{Políticas públicas de acesso à internet no Brasil em prol da efetividade do direito à comunicação}

O Estado brasileiro tem, há algum tempo, iniciado diversos projetos no sentido de dar maior efetividade ao direito à comunicação no país. Muito antes de se pensar em massificação do acesso à banda larga ou em convergência tecnológica, discutia-se de que forma seria possível garantir ao maior número de pessoas possível a utilização do Serviço de Telefonia Fixa Comutada (STFC).

Obviamente, o gérmen das discussões sobre universalização de serviços públicos e, especialmente, dos serviços de telecomunicações, é muito anterior a esse período relativamente curto de vigência do modelo de agências reguladoras e privatização do Sistema Telebrás, no qual ganharam força as políticas e os planos nacionais tendentes à universalização da telefonia fixa no país. ${ }^{90}$

${ }^{89}$ CASTELLS, Manuel. Op. cit., p. 135.

${ }^{90}$ Para um histórico detalhado da evolução dos serviços de telecomunicações no Brasil, ver: ARANHA, Márcio Iorio. Políticas públicas comparadas de Revista de Direito, Estado e Telecomunicações, v. 3, n. 1, p. 205-280 (2011) 
Neste capítulo, tem-se por objetivo, após breve intróito acerca da preocupação com a universalização do STFC no Brasil e a evolução para as discussões sobre a massificação da banda larga, no contexto da convergência digital, analisar algumas das políticas públicas adotadas pelo Governo Federal para ampliar o acesso à internet, bem como discutir a sua (in)efetividade à luz das demandas nacionais.

Apenas como preâmbulo de tais pontos, retome-se importante lição de Castells acerca da necessidade de implementação de políticas públicas para a garantia da efetividade de direitos fundamentais:

De outra parte, como já demonstrado a partir das considerações tecidas a respeito da obra de Holmes e Sunstein, não apenas os direitos econômicos, sociais e culturais implicam políticas públicas, mas também os direitos habitualmente designados de individuais ou identificados (no nosso sentir equivocadamente) com os direitos de liberdade, já que para assegurar a efetividade de qualquer direito não há como prescindir da alocação de toda uma gama de recursos públicos, de uma política de segurança, entre outras medidas que aqui se poderia referir. De qualquer modo, não há também como desconsiderar a magnitude da lição do eminente articulista, ao demonstrar que a efetivação dos direitos sociais, econômicos e culturais sempre envolve (embora não exclusivamente), de algum modo, a definição e implementação de políticas públicas, ainda mais em se tomando tal conceito em sentido amplo. ${ }^{91}$

De início, portanto, far-se-á breve descrição da passagem das preocupações relativas às políticas públicas envolvendo o STFC para as iniciativas referentes à massificação do acesso à internet, à luz da necessidade da efetivação do direito fundamental à comunicação no Brasil mediante implementação de políticas públicas.

telecomunicações (Brasil-EUA). Tese de doutorado. Centro de Pesquisa e PósGraduação sobre as Américas, da Universidade de Brasília. Brasília: UnB, 2005. ${ }^{91}$ CASTELLS, Manuel. A Sociedade em Rede - A era da informação: economia, sociedade e cultura. Vol. 1. Trad. Roneide Venâncio Majer. São Paulo: Paz e Terra, 1999. p. 225. 


\section{Da universalização do STFC às políticas públicas de acesso à internet}

O quadro do setor de telecomunicações brasileiro, no início da década de 1960, à época da vigência da Constituição de 1946, revelava que a exploração dos serviços de telecomunicações cabia à União, aos Estados e aos Municípios, em suas respectivas esferas, diretamente ou mediante outorga. Havia, nesse período, cerca de mil e duzentas empresas telefônicas no país, sendo a maioria de médio e pequeno porte, sem nenhuma coordenação entre si e sem compromisso com diretrizes comuns de desenvolvimento e de integração dos sistemas, o que representava um enorme obstáculo à eficiência e ao desenvolvimento do setor. ${ }^{92}$

Percebia-se, naquele momento, uma enorme concentração dos serviços telefônicos na região centro-leste do País, onde se encontravam mais de $60 \%$ dos terminais, explorados pela CTB (Companhia Telefônica Brasileira), de capital canadense. Além disso:

Os serviços telefônicos interurbanos eram precaríssimos, baseados apenas em algumas ligações em microondas de baixa capacidade, interligando 0 Rio de Janeiro, São Paulo, Campinas, Belo Horizonte e Brasília, e em poucos circuitos de rádio na faixa de ondas curtas. As comunicações telefônicas e telegráficas internacionais, também incipientes, eram exploradas por algumas poucas empresas estrangeiras. ${ }^{93}$

Dada a necessidade de se alterar a realidade do setor, foi editado o Código Brasileiro de Telecomunicações (Lei $\mathrm{n}^{\circ} 4.117$, de 27 de agosto de 1962), cujas principais disposições tinham por objetivo assegurar a prestação, de forma integrada, de todos os serviços de telecomunicações, bem como autorizar o Poder Executivo a constituir empresa pública para explorar industrialmente os troncos integrantes do Sistema Nacional de Telecomunicações. Essa empresa viria a ser a EMBRATEL.

\footnotetext{
${ }^{92}$ Os dados e as informações aqui utilizadas constam do Acervo Bibliográfico do Portal da Anatel, no documento "BRASIL. Ministério das Comunicações. Diretrizes Gerais para a Abertura do Mercado de Telecomunicações - Sumário Executivo." Disponível em: http://www.anatel.gov.br/Portal/exibirPortalInternet.do\#. Acesso em 30 de outubro de 2009. ${ }^{93}$ Idem.
} 
Aos poucos, o recém-criado Conselho Nacional de Telecomunicações (CONTEL) passou a exercer a missão de orientação da política e de fixação de diretrizes para o setor de telecomunicações. A EMBRATEL, constituída em 16 de setembro de 1965, lançou-se à tarefa de interligar todas as capitais e as principais cidades do país. Entre 1969 e 1973, a EMBRATEL assumiu a exploração dos serviços internacionais, à medida que expiravam os prazos de concessão das empresas estrangeiras que os operavam.

A criação da Telebras foi efetivada em 1972, pela Lei $\mathrm{n}^{\circ}$ 5.792, sobretudo em face da percepção da necessidade de haver uma entidade pública destinada a planejar e coordenar as telecomunicações de interesse nacional, bem como obter os recursos financeiros necessários à implantação de sistemas e serviços de telecomunicações, além de controlar a aplicação de tais recursos mediante participação acionária nas empresas encarregadas da operação desses sistemas e serviços.

Essa mesma lei, além de autorizar a criação da Telebras, autorizou a transformação da EMBRATEL em sociedade de economia mista, subsidiária da Telebras, sendo que esta estava vinculada ao Ministério das Comunicações. Logo após sua criação, a Telebras iniciou o processo de aquisição e absorção das empresas que prestavam serviços telefônicos no Brasil, visando consolidá-las em empresas de âmbito estadual. Havia nessa época mais de novecentas operadoras independentes no Brasil e, no total, uma planta de cerca de dois milhões de terminais. ${ }^{94}$

Apesar de a atuação da Telebras ter resultado na ampliação da planta instalada de terminais telefônicos, o tráfego telefônico aumentava em proporções enormes. Assim, a demanda por serviços era muito superior à capacidade existente para o seu atendimento.

Verificava-se também que mais de $80 \%$ dos terminais residenciais concentravam-se nas famílias das classes "A" e "B". Some-se a isso o fato de que a penetração dos serviços nas áreas rurais era praticamente nula, dentre outros fatores relevantes, e se entenderá a conclusão do Governo no sentido de que as empresas sob controle acionário estatal eram incapazes de manter o nível necessário de investimentos ao longo do tempo, o que fez com que a taxa de crescimento da planta oscilasse aleatoriamente e fosse insuficiente para, pelo menos, se igualar à do crescimento da demanda, e

${ }^{94}$ Idem. 
mais insuficiente ainda para proporcionar o atendimento à demanda reprimida. ${ }^{95}$

A Emenda Constitucional $\mathrm{n}^{\circ}$ 8, de 15 de agosto de 1995, alterou o inciso XI e a alínea $a$ do inciso XII do artigo 21 da Constituição Federal ${ }^{96}$, com o objetivo de:

(...) flexibilizar o modelo brasileiro de telecomunicações, eliminando a exclusividade da concessão para exploração dos serviços públicos a empresas sob controle acionário estatal e buscando introduzir o regime de competição na prestação desses serviços, visando, em última análise, ao benefício do usuário e ao aumento da produtividade da economia brasileira. ${ }^{97}$

Em seguida, passou-se a considerar a formulação de um novo modelo institucional para as telecomunicações brasileiras. Havia, de forma clara, a preocupação de que esse sistema tivesse como referência os direitos dos usuários dos serviços de telecomunicações. Assim, deveria assegurar, basicamente: a) a busca do acesso universal aos serviços básicos de telecomunicações; b) o aumento das possibilidades de oferta de serviços, em termos de quantidade, diversidade, qualidade e cobertura territorial; c) a possibilidade de competição justa entre os prestadores de serviços; d) preços razoáveis para os serviços de telecomunicações.

Com a edição da Lei Geral de Telecomunicações (Lei $n^{\circ}$ 9.472), foi criada a Agência Nacional de Telecomunicações (Anatel), cujas competências foram estabelecidas nos incisos do artigo 19 da LGT. ${ }^{98}$

${ }^{95}$ Idem.

${ }^{96}$ Artigo 21. Compete à União: (...) XI - explorar, diretamente ou mediante autorização, concessão ou permissão, os serviços de telecomunicações, nos termos da lei, que disporá sobre a organização dos serviços, a criação de um órgão regulador e outros aspectos institucionais; XII - explorar, diretamente ou mediante autorização, concessão ou permissão: a) os serviços de radiodifusão sonora e de sons e imagens. ${ }^{97}$ BRASIL. Ministério das Comunicações. Diretrizes Gerais para a Abertura do Mercado de Telecomunicações - Sumário Executivo. Disponível em:

http://www.anatel.gov.br/Portal/exibirPortalInternet.do\#. Acesso em 30 de outubro de 2009.

${ }^{98}$ Art. 19. À Agência compete adotar as medidas necessárias para o atendimento do interesse público e para o desenvolvimento das telecomunicações brasileiras, atuando Revista de Direito, Estado e Telecomunicações, v. 3, n. 1, p. 205-280 (2011)

DOI: https://doi.org/10.26512/1str.v3i1.21671 
O objetivo de fortalecer o papel regulador do Estado, reduzindo-se sua atividade empresária, contempla a orientação de que o Estado deve promover um grau adequado de supervisão sobre o setor, de modo a assegurar que sejam alcançados os seus objetivos essenciais da reforma, com a criação de um mercado de competição efetiva e a proteção dos consumidores contra comportamentos anticoncorrenciais. ${ }^{99}$ Além disso, quis-se aumentar e melhorar a oferta de serviços, criando-se oportunidades atraentes de investimento e de desenvolvimento tecnológico e industrial e condições para que o desenvolvimento do setor fosse harmônico com as metas de desenvolvimento social do País. ${ }^{100}$

$\mathrm{O}$ cuidado de se estabelecerem metas relativas à universalização do serviço, notadamente do STFC, ao menos de início, partiu da noção de que, quanto aos mercados atraentes:

com independência, imparcialidade, legalidade, impessoalidade e publicidade, e especialmente: I - implementar, em sua esfera de atribuições, a política nacional de telecomunicações; (...) IV - expedir normas quanto à outorga, prestação e fruição dos serviços de telecomunicações no regime público; V - editar atos de outorga e extinção de direito de exploração do serviço no regime público; VI - celebrar e gerenciar contratos de concessão e fiscalizar a prestação do serviço no regime público, aplicando sanções e realizando intervenções; (...) X - expedir normas sobre prestação de serviços de telecomunicações no regime privado; XI - expedir e extinguir autorização para prestação de serviço no regime privado, fiscalizando e aplicando sanções; (...) XIV - expedir normas e padrões que assegurem a compatibilidade, a operação integrada e a interconexão entre as redes, abrangendo inclusive os equipamentos terminais; (...) XVIII - reprimir infrações dos direitos dos usuários.

${ }^{99}$ BRASIL. Ministério das Comunicações. Diretrizes Gerais para a Abertura do Mercado de Telecomunicações - Sumário Executivo. Disponível em:

http://www.anatel.gov.br/Portal/exibirPortalInternet.do\#. Acesso em 30 de outubro de 2009.

${ }^{100}$ Quanto ao ponto, mostrava-se essencial "[...] reduzir o diferencial de cobertura dos serviços de telecomunicações entre as diversas regiões do País e entre as diversas faixas de renda; criar condições para a prática de tarifas razoáveis e justas para os serviços de telecomunicações; promover serviços de telecomunicações que incentivem o desenvolvimento econômico e social do País; e alcançar metas específicas de serviço universal." (Idem). 
(...) as tarifas cobrem os custos operacionais e proporcionam retorno comercialmente atrativo ao capital investido, de modo que os provedores de serviço buscarão, normalmente, satisfazer a esses clientes como parte de sua estratégia de negócios. Ou seja, a competição na exploração dos serviços fará com que os consumidores economicamente atrativos sejam atendidos satisfatoriamente, tendo acesso a serviços que supram de forma adequada suas necessidades de telecomunicações. ${ }^{101}$

Quanto aos casos, porém, em que o custo de prover o acesso físico era elevado ou em que os clientes potenciais dispunham de renda inferior à que seria necessária para criar uma oportunidade de investimento atrativa para algum provedor de serviço. Nesse caso, o acesso a serviços de telecomunicações parecia, de fato, “(...) requerer algum tipo de subsídio, que deverá ser idealizado e distribuído de modo a não criar vantagens nem desvantagens para nenhum dos operadores e, ao mesmo tempo, possibilitar o atendimento a esse objetivo social ao menor custo." 102

Após a privatização do Sistema Telebras, diversos instrumentos normativos foram elaborados com o intuito de se atingirem os propósitos do novo modelo do setor, que incluía o objetivo de universalização do STFC. Mencione-se especialmente o Plano Geral de Metas de Universalização (PGMU), aprovado pelo Decreto 2.592, de 1998, cujas alterações posteriores serão referidas mais adiante.

Embora o sistema normativo vigente para as telecomunicações preserve o STFC como serviço essencial, há a percepção de que cuidados devem ser dedicados a outras linhas. É o caso do acesso à internet de alta velocidade, cuja demanda cresce significativamente e para o qual não há uma definição clara a respeito de metas a serem alcançadas, a despeito de já haver iniciativas nesse sentido.

O cenário da convergência digital, fenômeno cada vez mais abordado e que ganha relevância indiscutível no desenvolvimento nacional, requer do Estado, da iniciativa privada e da sociedade civil um posicionamento efetivo e firme quanto à adoção de políticas públicas e de medidas de mercado que

\footnotetext{
${ }^{101}$ Idem.

${ }^{102}$ Idem.
} 
favoreçam a disseminação e o avanço das tecnologias de informação (TIC) no cenário brasileiro.

Desse modo, percebe-se a necessidade de se discutirem meios para a efetivação de um modelo, no Brasil, que permita não apenas a ampliação do acesso aos serviços de telecomunicações e à internet, mas a efetivação de uma política racional de uso das tecnologias, de forma integrada e economicamente viável, a fim de que o desenvolvimento do país e os direitos individuais de comunicação sejam simultaneamente proporcionados.

\section{Iniciativas para a massificação da banda larga no Brasil}

Em face das novas demandas sociais existentes, dado o fato de que a internet constitui elemento central para o desenvolvimento e a participação na passagem para a sociedade em rede, faz-se necessário analisar as iniciativas brasileiras quanto à implementação de políticas públicas de acesso à internet, em especial quanto à utilização de banda larga.

É que o Estado brasileiro, à luz dos princípios constitucionais de 1988, vê-se jungido às obrigações de universalização que inspiraram o modelo relativo ao STFC, como se viu, especialmente na passagem do Sistema Telebras para a privatização do setor de telecomunicações, com importante atuação da Anatel nesse processo.

Seguindo a mesma trajetória, a despeito de não se tratar, juridicamente, de um serviço público, mas de um serviço de valor adicionado (SVA), nos termos da legislação vigente (Lei $n^{\circ}$ 9.472/97), o serviço de conexão à internet com razoável largura de banda torna-se preocupação central do Estado, no que diz respeito à massificação do acesso. Isso ocorre também à luz de tudo que se expôs anteriormente, quanto à fundamentalidade do direito à comunicação e de seu caráter trivalente, que permite, portanto, a exigência de uma postura positiva de prestação por parte do Poder Público.

Assim, serão mencionadas algumas das principais iniciativas do Estado brasileiro no que diz respeito à massificação do acesso à banda larga, para, em seguida, se discutir o alcance e a efetividade das políticas adotadas, diante das demandas já existentes e que provavelmente surgirão nos próximos anos. 


\section{Backhaul}

Dentro dos projetos tendentes à universalização do STFC no Brasil, havia a previsão, no artigo $3^{\circ}$, do Anexo ao Decreto 4.769/2003, que aprovou o Plano Geral de Metas para a Universalização do Serviço Telefônico Fixo Comutado Prestado no Regime Público (PGMU), de que as concessionárias do Serviço Telefônico Fixo Comutado destinado ao uso do público em geral (STFC) deveriam cumprir uma série de obrigações, enumeradas no referido decreto, dentre elas a de ativação de Postos de Serviços de Telecomunicações (PST). ${ }^{103}$

Segundo a definição legal, os PST seriam conjuntos de instalações de uso coletivo, mantidos pela concessionária, constituídos de pelo menos quatro Telefones de Uso Público (TUP) e quatro Terminais de Acesso Público (TAP), permitindo (i) a utilização do STFC, por meio de acesso de uso coletivo, (ii) a conexão a Provedores de Acesso a Serviços Internet (PASI) de livre escolha do usuário, (iii) o envio e recebimento de textos, gráficos e imagens por meio eletrônico, independentemente de assinatura ou de inscrição do usuário junto à prestadora.

As previsões do PGMU encontravam-se em consonância ao disposto no artigo 80 da Lei Geral de Telecomunicações (Lei nº 9.472/1997):

${ }^{103}$ Confira-se o teor do mencionado artigo do Anexo ao Decreto n. ${ }^{0}$ 4.769/2003(PGMU): Art. 3. ${ }^{\circ}$ Para efeitos deste Plano são adotadas as definições constantes da regulamentação, em especial as seguintes: (...) VIII - Posto de Serviço de Telecomunicações - PST é um conjunto de instalações de uso coletivo, mantido pela concessionária, dispondo de, pelo menos, TUP e TAP, e possibilitando o atendimento pessoal ao consumidor; IX - Serviço Telefônico Fixo Comutado destinado ao uso do público em geral (STFC) é o serviço de telecomunicações que, por meio da transmissão de voz e de outros sinais, destina-se à comunicação entre pontos fixos determinados, utilizando processos de telefonia; $X$ - Telefone de Uso Público - TUP é aquele que permite, a qualquer pessoa, utilizar, por meio de acesso de uso coletivo, o STFC, independentemente de assinatura ou inscrição junto à prestadora; XI - Terminal de Acesso Público - TAP é aquele que permite, a qualquer pessoa, utilizar, por meio de acesso de uso coletivo, o STFC, independentemente de assinatura ou inscrição junto à prestadora, incluindo, ainda, funções complementares que possibilitem o uso do STFC para conexão a Provedores de Acesso a Serviços Internet - PASI, de livre escolha do usuário, e envio e recebimento de textos, gráficos e imagens, por meio eletrônico, observado o disposto na regulamentação.

Revista de Direito, Estado e Telecomunicações, v. 3, n. 1, p. 205-280 (2011)

DOI: https://doi.org/10.26512/1str.v3i1.21671 
Art. 80. As obrigações de universalização serão objeto de metas periódicas, conforme plano específico elaborado pela Agência e aprovado pelo Poder Executivo, que deverá referir-se, entre outros aspectos, à disponibilidade de instalações de uso coletivo ou individual, ao atendimento de deficientes físicos, de instituições de caráter público ou social, bem como de áreas rurais ou de urbanização precária e de regiões remotas.

$\S 1^{\circ} \mathrm{O}$ plano detalhará as fontes de financiamento das obrigações de universalização, que serão neutras em relação à competição, no mercado nacional, entre prestadoras.

$\S 2^{\circ}$ Os recursos do fundo de universalização de que trata 0 inciso II do art. 81 não poderão ser destinados à cobertura de custos com universalização dos serviços que, nos termos do contrato de concessão, a própria prestadora deva suportar.

Entretanto, iniciou-se controvérsia acerca da adequação dos PST aos objetivos desejados no sentido de se promover a inclusão digital da população brasileira e de se ampliar o acesso a novas tecnologias, para além da simples universalização do STFC. Tal questionamento encontrava amparo no disposto no artigo $2^{\circ}, \S 2^{\circ}$, do Decreto ${ }^{\circ}$ 4.769/2003 (PGMU):

Art. 2. ${ }^{\circ}$ Este Plano estabelece as metas para a progressiva universalização do STFC prestado no regime público, a serem cumpridas pelas concessionárias do serviço, nos termos do art. 80 da Lei n. ${ }^{\circ}$ 9.472, de 1997.

$\S 1$ 1. $^{\circ}$ Todos os custos relacionados com o cumprimento das metas previstas neste plano serão suportados, exclusivamente, pelas Concessionárias por elas responsáveis, nos termos fixados nos respectivos contratos de concessão.

$\S 2 .^{\circ}$ A Agência Nacional de Telecomunicações - Anatel, em face de avanços tecnológicos e de necessidades de serviços pela sociedade, poderá propor a revisão do conjunto de metas que objetivam a universalização do serviço, observado o disposto nos contratos de concessão, bem como propor metas complementares ou antecipação de metas estabelecidas neste Plano, a serem cumpridas pelas prestadoras do STFC, definindo, nestes casos, fontes para seu financiamento, nos termos do art. 81 da Lei n. ${ }^{\circ} 9.472$, de 1997.

Cogitou-se, desse modo, a possibilidade de se alterar a infraestrutura do STFC, em face da percepção de que a velocidade de acesso às redes de 
dados de $64 \mathrm{Kbit} / \mathrm{s}$ e a obrigação de implantação de Postos de Serviços de Telecomunicações (PST) estabelecidas pela regulamentação seriam insuficientes para promover a inclusão digital.

A verificação de que a deficiente infraestrutura de telecomunicações podia ser considerada uma das principais barreiras para a inclusão digital no Brasil estimulou a adoção de medidas para alterar essa realidade.

Dita infraestrutura pode ser entendida como a soma de dois elementos essenciais para que o serviço possa chegar até o cidadão: o backhaul, infraestrutura de alta capacidade necessária para interligar as redes de acesso à internet pública; e as redes de acesso à internet em banda larga, que compõem a última milha necessária à conexão do ambiente do usuário ao do prestador de serviços.

Assim, o backhaul é a infraestrutura de rede de suporte do Serviço de Telefonia Fixa Comutada (STFC) para conexão em banda larga, interligando as redes de acesso ao backbone da operadora. O backhaul visa a conectar os municípios brasileiros que ainda não possuem oferta de serviços banda larga no varejo, a partir de municípios já atendidos.

Pensou-se, então, na adoção de metas alternativas às então estabelecidas no Anexo ao Decreto 4.769/2003 (PGMU), para permitir a instalação de backhaul de internet em banda larga em todos os municípios do país, acompanhada de iniciativas de difusão das redes de acesso, substituindo-se, para tanto, a obrigação de instalação dos PST.

Essa solução decorreu da constatação de que a LGT admite a alteração do PGMU devido à periodicidade das metas de universalização previstas. Assim, a substituição das obrigações de ativação de PST pela obrigação de aumento da capacidade das redes de STFC, com a instalação de backhaul, objetiva fazer com que tais estruturas tornem-se aptas a suportar a prestação de serviço de transmissão de dados em alta velocidade - banda larga - para acesso à internet.

Em parecer emitido sobre a matéria, Carlos Ari Sundfeld defende que as novas obrigações teriam finalidade de interesse público, qual seja, levar a localidades atualmente não atendidas pela internet em alta velocidade uma infraestrutura de rede (backhaul) a ser utilizada por operadores de serviços 
de telecomunicações para a oferta de serviços de acesso à internet a usuários finais. ${ }^{104}$

A viabilidade jurídica da substituição reside no fato de que a nova meta de universalização geraria apenas o incremento da capacidade da rede de telefonia fixa. Desse modo, a oferta de internet em alta velocidade a usuários finais não estaria incluída na meta, sendo feita sob regime privado por prestadores do serviço de interesse coletivo denominado Serviço de Comunicação Multimídia (SCM), regido pela Resolução n. 272/2001, da Anatel.

Como explicam Duarte e Silva, em informe sobre o backhaul:

(...) a ampliação da capacidade das suas próprias redes pode ser legitimamente inserida no rol de atribuições das concessionárias de STFC. Este serviço, além da importante função de propiciar a usuários finais a comunicação pessoal, funciona como rede básica para 0 oferecimento de outros serviços de telecomunicações. Essa outra aplicação ocorre por intermédio da exploração industrial das redes do STFC. ${ }^{105}$

Verifica-se, desse modo, que as redes de telecomunicações podem ser utilizadas para a prestação de outros serviços, além daqueles para os quais foram originalmente instaladas, sendo esta inclusive uma “(...) diretriz da LGT, que conferiu à Anatel poderes para impor o compartilhamento de redes como forma de incentivo à competição (art. 155, LGT)."106

As referidas autoras do informe citado concluem, então, que a prestação do STFC proporciona não apenas a fruição do serviço de telefonia pelos usuários, mas também “(...) a disponibilização da capacidade excedente de sua rede para dar suporte à prestação, por utentes industriais, de outros serviços de telecomunicações."107

${ }^{104}$ SUNDFELD, Carlos Ari. Parecer. In: Processo $\mathrm{n}^{\mathrm{o}}$ 53000.026882/2007-84 (Ministério das Comunicações). São Paulo, 6 de junho de 2007, p. 14-17.

${ }^{105}$ DUARTE, Denianne de Araújo; SILVA, Lívia Denise Rêgo. Backhaul ameaçado, consumidor atento. In: RDET 1(1): 223 (2009).

${ }^{106}$ DUARTE, Denianne de Araújo; SILVA, Lívia Denise Rêgo. Op. cit., p. 224. ${ }^{107}$ Idem. 
A grande interrogação a respeito do backhaul, porém, reside no fato de o provimento de internet ou a oferta de serviço de transmissão de dados em alta velocidade não ser juridicamente definido como serviço de telecomunicação. A LGT classifica-o como Serviço de Valor Adicionado (SVA), isto é, aquele que faz uso de telecomunicação para ser prestado, mas que com ela não se confunde (art. 61, LGT). ${ }^{108} \mathrm{O}$ acesso à internet é possibilitado pelo Serviço de Comunicação Multimídia (SCM), prestado em regime privado.

Duarte e Silva explicam ainda, a partir do parecer emitido por Sundfeld, que:

(...) o proveito coletivo da medida, apesar de estar diretamente vinculado ao acesso à internet - e, portanto, à fruição do SCM - seria proporcionado pela rede de STFC. A obrigação de universalização, no caso, atenderia de modo instrumental ao objetivo final almejado, qual seja, a inclusão digital da maior parte da população brasileira. A oferta de banda larga continuaria sem subsídio direto, ocorrendo em regime de ampla competição entre as prestadoras interessadas. Com a criação do backhaul na rede de STFC, as prestadoras de SCM (utentes industriais) passariam a ter condições materiais de atuar em localidades que, devido ao seu porte, não atraíam os investimentos necessários à constituição da infraestrutura básica à sua existência. O STFC proporcionaria esse investimento, permitindo, com isso, o acesso de prestadoras de outros serviços de interesse público a usuários anteriormente desatendidos. ${ }^{109}$

Sundfeld assevera, portanto, que a inserção de metas de universalização substitutivas aos PST, que representem investimentos vinculados a elementos de redes de quaisquer das concessões da mesma empresa, é juridicamente possível, à luz do modelo do Plano Geral de Outorgas (PGO) e da competência das autoridades administrativas para estabelecer o sistema de metas de universalização, a partir do PGO e do PGMU. ${ }^{110}$

\footnotetext{
${ }^{108}$ Art. 61. Serviço de valor adicionado é a atividade que acrescenta, a um serviço de telecomunicações que lhe dá suporte e com o qual não se confunde, novas utilidades relacionadas ao acesso, armazenamento, apresentação, movimentação ou recuperação de informações.

${ }^{109}$ DUARTE, Denianne de Araújo; SILVA, Lívia Denise Rêgo. Op. cit., p. 224-225. ${ }^{110}$ SUNDFELD, Carlos Ari. Op. cit., p. 25-26.
}

Revista de Direito, Estado e Telecomunicações, v. 3, n. 1, p. 205-280 (2011)

DOI: https://doi.org/10.26512/1str.v3i1.21671 
Deve haver, contudo, como também ponderam Duarte e Silva, o cuidado de se manter o “(...) equilíbrio econômico-financeiro, ou seja, a confrontação entre os encargos oriundos da universalização e a perspectiva de receita deve produzir resultado equivalente antes e depois da substituição das metas."111

A substituição dos PST pela obrigação de instalação do backhaul foi firmada pelo Decreto 6.424/2008, que alterou o Decreto 4.769/2003 (PGMU) e estabeleceu a necessidade de as empresas de telefonia fixa levarem redes de internet a todos os municípios do país.

Estabeleceram-se as seguintes metas para as concessionárias, consoante a nova redação do artigo 13, caput e incisos, do Decreto 4.769/2003: instalar o backhaul em 40\% dos municípios, até 31 de dezembro de 2008; $80 \%$ dos municípios, até 31 de dezembro de 2009; e 100\% dos municípios, até 31 de dezembro de 2010. Há ainda a imposição de se respeitar uma capacidade mínima de transmissão, segundo o novo art. 13-A do Decreto 4.769/2003, que variará de acordo com a população de cada município, e sujeita a alterações em face da evolução tecnológica.

Dados da Anatel indicam que, até dezembro de 2009, mais de dois mil municípios estavam atendidos e que, até o fim de 2010, todos os municípios brasileiros seriam alcançados pelo backhaul. ${ }^{112}$

Apesar de ter sido alvo de críticas e inclusive ações judiciais ${ }^{113}$, o objetivo do backhaul coaduna-se com o discurso do Governo Federal de assegurar a infraestrutura necessária para a inclusão digital no país. Entretanto, por se tratar tão-somente de obrigações de instalação de infraestrutura que possibilita a prestação de provimento à internet banda larga, é necessário associar a instalação do backhaul a outras políticas públicas, que tenham o condão de implementar, de fato, o acesso e inserir os

${ }^{111}$ DUARTE, Denianne de Araújo; SILVA, Lívia Denise Rêgo. Op. cit., p. 225.

${ }^{112}$ Dados apresentados pelo Presidente da Anatel, Ronaldo Sardenberg, no Seminário "A universalização do acesso à informação pelo uso das telecomunicações", promovido pelo Conselho de Altos Estudos da Câmara dos Deputados, no dia 29 de setembro de 2009.

${ }^{113}$ Sobre esse histórico de discussões e controvérsias judiciais envolvendo o backhaul, conferir: DUARTE, Denianne de Araújo; SILVA, Lívia Denise Rêgo. Op. cit. 
cidadãos no contexto da sociedade em rede. É o objetivo, por exemplo, do Programa Banda Larga nas Escolas.

\section{Programa Banda Larga nas Escolas}

Uma iniciativa aclamada pelo Governo Federal, em defesa de sua anunciada preocupação com a massificação do acesso à internet, é o programa chamado "Banda Larga nas Escolas". Trata-se de política pública voltada essencialmente a assegurar o acesso à internet em alta velocidade nas escolas públicas brasileiras, com metas a serem cumpridas até 2010, quando se espera que todas elas já tenham recebido seus modems.

O referido programa surgiu como consequência da alteração do Plano Geral de Metas de Universalização (PGMU), por meio da qual se substituiu a obrigação das concessionárias de instalarem os PST pela necessidade de instalarem o backhaul. Também como ônus para as concessionárias, previuse a doação do primeiro modem às escolas, que deverão mantê-lo.

Durante o prazo de duração do projeto (2008-2025), as concessionárias deverão aumentar gradativamente a velocidade da conexão, que iniciou em 1 Mbps.

Segundo dados da Anatel de julho de 2009, aproximadamente trinta mil escolas públicas urbanas brasileiras já detinham conexão banda larga, o que representa mais de $50 \%$ do total. ${ }^{114}$

À luz desses dados, a iniciativa tem sido exaltada pelos membros do Governo, que destacam a importância da banda larga para a educação no país. O "Banda Larga nas Escolas" compõe o conjunto de medidas do Programa Nacional de Informática na Educação (Proinfo), que tem como objetivo fundamental a informatização do ensino, mediante a instalação de computadores e a capacitação de professores da rede pública em todo o país. ${ }^{115}$

\footnotetext{
${ }^{114}$ Notícia veiculada em http://www.inclusaodigital.gov.br/inclusao/noticia/programa-bandalarga-nas-escolas-atende-mais-da-metade-das-escolas-publicas-urbanas-do-pais. Acesso em 28 de outubro de 2009.

${ }^{115}$ Notícia veiculada em http://www.agenciabrasil.gov.br/noticias/2008/04/07/materia.200804-07.3055799025/view. Acesso em 28 de outubro de 2009.
}

Revista de Direito, Estado e Telecomunicações, v. 3, n. 1, p. 205-280 (2011)

DOI: https://doi.org/10.26512/1str.v3i1.21671 


\section{Plano Nacional de Banda Larga}

$\mathrm{O}$ grande debate que há no país, neste momento, quanto à massificação da banda larga diz respeito ao chamado Plano Nacional de Banda Larga, lançado oficialmente por meio do Decreto 7.175, de 12 de maio de 2010.

Diversos setores da sociedade, inclusive concessionárias de STFC e membros do Governo, manifestaram-se em defesa da elaboração de um projeto nacional que visasse à massificação do acesso à internet de alta velocidade. ${ }^{116}$

A Secretaria de Assuntos Estratégicos (SAE) da Presidência da República começou a trabalhar, ao lado do Ministério das Comunicações e de outros entes governamentais, no sentido de propor medidas que compusessem o referido plano. Também os Ministérios da Cultura e da Educação participaram das discussões.

O plano é estruturado "em quatro grandes dimensões", descritas da seguinte forma:

(i) ações regulatórias que incentivem a competição e normas de infraestrutura que induzam à expansão de redes de telecomunicações;

(ii) incentivos fiscais e financeiros à prestação do serviço de acesso em banda larga, com o objetivo de colaborar para 0 barateamento do custo ao usuário final;

(iii) uma política produtiva e tecnológica, capaz de atender adequadamente à demanda gerada pelo PNBL; e

(iv) uma rede de telecomunicações nacional, com foco de atuação no atacado, neutra e disponível para qualquer prestadora que queira prestar o serviço de acesso em banda larga. ${ }^{117}$

\footnotetext{
${ }^{116}$ Como exemplo, mencione-se a posição do Presidente da Abrafix (Associação Brasileira de Concessionárias do Serviço Telefônico Fixo Comutado), José Fernandes Pauletti, que defende a utilização dos recursos do Fust (Fundo de Universalização dos Serviços de Telecomunicações) para que se reduza o custo da banda larga, subsidiando-se 0 serviço. Disponível em: http://www.telesintese.ig.com.br/index.php?option=com_content\&task=view\&id=10571\&Itemi $\mathrm{d}=105$. Acesso em 20 de janeiro de 2009.

${ }^{117}$ Disponível em: http://www4.planalto.gov.br/brasilconectado/pnbl/implantacao-edesenvolvimento. Acesso em 20 de novembro de 2010.
} 
As medidas práticas serão implantadas em diferentes fases, mas a opinião de executivos da iniciativa privada é de que o Estado precisaria reduzir os custos inerentes ao serviço, principalmente a carga tributária, pois as empresas dependem da obtenção de retorno dos investimentos efetuados, o que ocorre nos mercados de alta densidade e alta renda, nos quais a competição é maior.

Nota-se que a ideia dos membros do Governo Federal é oferecer o serviço de banda larga por preços acessíveis à população de baixa renda, notadamente as classes "C", "D" e "E". O Ministério das Comunicações trabalhou na elaboração de propostas que possibilitem encontrar formas de financiamento para se chegar a trinta milhões de acessos fixos e sessenta milhões de acessos móveis até 2014, a um custo de $\mathrm{R} \$ 15,00$ (quinze reais) por mês (pacote básico).

Muitos países hoje têm estabelecido planos semelhantes com o objetivo de possibilitar acesso universal à internet banda larga. Paralelamente, em alguns casos, há enfoques específicos na viabilização de condições técnicas para acesso a redes de alta capacidade. No Japão, busca-se eliminar completamente as áreas sem conexão de banda larga, mas há uma meta de se alcançar, simultaneamente, a utilização de altas velocidades por $90 \%$ da população. A Alemanha visa a oferecer, em todo o seu território, o serviço de $1 \mathrm{Mbps}$, enquanto ambiciona também uma cobertura de $75 \%$ da nação a uma velocidade de 50Mbps.

A universalidade é acompanhada de outra preocupação, que é a de ofertar as mais altas tecnologias possíveis. Parece, de fato, ser tão importante quanto oferecer capacidade razoável a toda população assegurar também alta capacidade de conexão segundo os padrões internacionais, a fim de proporcionar condições adequadas para o desenvolvimento.

\section{A realidade brasileira e a busca da efetividade do direito à comunicação: entre a pobreza digital e a sociedade em rede}

As diversas iniciativas que se verificam no país com a finalidade de se ampliar o acesso à internet em alta velocidade e incluir mais pessoas no contexto da sociedade em rede demonstram o reconhecimento, hoje praticamente unânime, de que o desenvolvimento pessoal e nacional, na realidade hodierna, só é possível mediante a garantia dos meios essenciais para o exercício do direito à comunicação. 
De fato, o Brasil ainda pode ser caracterizado como uma sociedade de pobreza digital, em que apenas uma minoria tem acesso à internet de forma satisfatória. Aliás, em verdade, o que se tem é um analfabetismo digital, que corrobora a noção já exposta de que não basta garantir o acesso, mas é indispensável capacitar as pessoas a utilizar os recursos comunicacionais que lhes são oferecidos, a fim de que se reconheça a utilidade destes para melhorar as condições de trabalho, de educação, de relacionamentos interpessoais, de acompanhamento das atividades governamentais, entre tantas outras possibilidades.

Percebe-se que as esperanças, no tocante especificamente à banda larga, têm se concentrado no Plano Nacional, recentemente lançado como resultado de um esforço em diversas frentes, envolvendo órgãos do Governo, especialistas técnicos do setor de telecomunicações, operadoras e concessionárias, membros da sociedade civil, enfim.

Naturalmente, não é possível afirmar que esse plano resolverá todos os problemas brasileiros relativos à transição para a era informacional da sociedade em rede. Deve-se, entretanto, prestigiar o enfoque dado ao tema e a preocupação da sociedade e do Estado brasileiros quanto a essas questões fundamentais.

$\mathrm{O}$ que se verifica é que, sejam quais forem as propostas e metas praticadas na concretização do plano, far-se-á necessário um trabalho em parceria de todos os envolvidos para que se assegurem, concretamente, os meios estruturais tecnológicos e de qualificação técnica para o eficaz aproveitamento das redes.

A iniciativa de se buscar a inclusão digital a partir das escolas públicas deve ser louvada, mas é imprescindível o acompanhamento próximo das obrigações das concessionárias, em relação aos planos de metas a elas impostos, para que os objetivos de ampliação do acesso sejam atingidos.

Contudo, é igualmente indispensável que essa missão seja acompanhada, como já se referiu, de programas que permitam aos jovens aprenderem a utilizar as tecnologias e os recursos ofertados, sob pena de a possibilidade do acesso pouco ou nada representar de útil às suas realidades. É o que Faraco expõe claramente do seguinte modo:

Primeiro, o acesso às novas tecnologias exige um conjunto de habilidades técnicas maiores do que aquelas necessárias para que 0 
usuário possa se beneficiar do serviço de telefonia. Isso significa que a difusão do acesso precisa ser pensada em conjunto com a difusão do conhecimento específico necessário para utilizá-lo. Não basta, portanto, conceber como a rede chegará a certas pessoas, mas de que forma elas poderão adquirir o conhecimento a partir do qual podem perceber e fruir das possibilidades da tecnologia. ${ }^{118}$

Parece que esse é o grande ponto de interrogação no que diz respeito às políticas públicas brasileiras. Esforça-se sobremaneira para concluir de que forma o acesso pode ser assegurado ao maior número de pessoas possível, inclusive com a preocupação de estimular as empresas a ofertarem o serviço em locais de baixa renda, cujos mercados são economicamente inviáveis, mediante subsídios e outros incentivos, além do estabelecimento de metas de universalização, como se verifica no caso do STFC. No entanto, deveria caminhar no mesmo ritmo a discussão acerca de como, uma vez garantido o acesso, as pessoas aprenderão a manusear microcomputadores e utilizar a internet de forma a atender suas necessidades específicas. Como exemplo, veja-se a hipótese lançada por Faraco de um lavrador que pode utilizar a internet para pesquisar melhores técnicas para as suas culturas, ou ainda para se informar a respeito das condições climáticas da região. É preciso que tais possibilidades lhe sejam apresentadas, a fim de que a tecnologia se mostre relevante naquele contexto.

É óbvio que soa paradoxal falar em capacitação e qualificação quando sequer há a estrutura que possibilite o acesso à tecnologia. Não se pretende aqui criticar as políticas voltadas à garantia do acesso à internet, mas apontar para a importância de as preocupações caminharem juntas, uma vez que uma só faz sentido se aliada à outra.

Esse ponto de vista é reforçado também pelo fato de que, a depender da forma pela qual se pretende ensinar e capacitar as pessoas, pode-se fazer necessário adaptar a infraestrutura a um ou outro modo de organização e planejamento. Daí a relevância de se estabelecerem metas de educação e verdadeira inclusão digital, para além da mera garantia do acesso.

${ }^{118}$ FARACO, Alexandre Ditzel. Democracia e regulação das redes eletrônicas de comunicação - rádio, televisão e internet. Belo Horizonte: Editora Fórum, 2009. Pp. 307.

Revista de Direito, Estado e Telecomunicações, v. 3, n. 1, p. 205-280 (2011)

DOI: https://doi.org/10.26512/1str.v3i1.21671 
Novamente deve-se recorrer a Alexandre Faraco, que demonstra preocupação quanto à urgência dessas questões:

Ademais, o modo como se concebe 0 acesso coletivo precisa tomar em consideração as necessidades mais prementes de dada comunidade, do contrário o seu uso não será compreendido como efetivamente relevante e a possibilidade de representar uma melhoria significativa na vida das pessoas não se concretizará. A internet oferece inúmeras funcionalidades (ao contrário da uniformidade da telefonia), mas nem todas são percebidas com o mesmo grau de relevância ou identificáveis a partir da mera existência do acesso. Numa comunidade rural mais isolada, por exemplo, podem existir carências básicas de informação sobre condições climáticas ou preço de mercadorias, que são vistas como muito mais relevantes do que a possibilidade de enviar ou receber emails ou acessar vídeos no YouTube. A compreensão de que tais necessidades podem ser supridas pelo acesso à internet será determinante para que a nova tecnologia seja percebida como útil e desperte um maior interesse quanto às demais possibilidades que oferece. ${ }^{119}$

Um ponto que merece especial destaque em relação ao trecho acima transcrito é o que diz respeito às diferenças entre a internet e a telefonia. É que, enquanto esta é marcada pela uniformidade, uma vez que permite apenas a transmissão de voz, a internet representa múltiplas possibilidades, que são ampliadas diariamente, dada a sua abertura para a interferência do usuário, que a constrói segundo suas necessidades e preferências.

Por isso, não se podem transpor para a internet todos os elementos que pautaram as políticas de universalização da telefonia, dada a especificidade do serviço de que se cuida e que representa enorme oportunidade de desenvolvimento em todas as áreas.

Outro elemento essencial que deve nortear o estabelecimento das metas relativas à massificação do acesso e à inclusão digital é a percepção das peculiaridades locais das comunidades atendidas. $\mathrm{O}$ interesse pela tecnologia depende, em grande medida, do reconhecimento da utilidade daquela ferramenta para a melhoria das condições de determinada realidade.

\footnotetext{
${ }^{119}$ FARACO, Alexandre Ditzel. Democracia e regulação das redes eletrônicas de comunicação: rádio, televisão e internet. Belo Horizonte: Editora Fórum, 2009. p. 307-308.
} 
Assim, não se pode pretender que as pessoas passem a utilizar a internet de modo uniforme e padronizado, segundo um modelo pré-estabecido de capacitação. A essência da internet é a liberdade, daí porque a qualificação deve levar em conta os anseios e as necessidades próprias às comunidades locais.

Se o Brasil não vive mais numa sociedade de completa pobreza digital, também não se pode afirmar que o país já se encontra plenamente inserido no contexto global da sociedade em rede. Trata-se de caminho a ser ainda percorrido.

Espera-se que, com o diálogo estabelecido para a formulação do Plano Nacional de Banda Larga, Estado e empresas, principais atores desse processo, cheguem a um ponto comum que permita maior rapidez e eficiência para a inclusão digital no Brasil. Necessariamente, deverá haver medidas regulatórias voltadas a ambas as partes, por exemplo, com reduções na carga tributária, estabelecimento de metas, oferta de subsídios, entre outras. O importante, contudo, é que se reconheçam como elementos indispensáveis, na dinâmica regulatória, a concretização do acesso e a capacitação das pessoas, a fim de inserir não apenas o Brasil, mas principalmente os brasileiros na era informacional.

\section{Considerações finais}

O ponto de partida para a análise realizada foi a constatação de que o rol de direitos fundamentais existente na Constituição Federal de 1988 é exemplificativo, por expressa disposição constitucional ( $\operatorname{art} .5^{\circ}, \S 2^{\circ}$ ), o que permite a verificação da necessidade de se assegurarem novos direitos fundamentais, à luz das transformações sociais, culturais, políticas ou econômicas por que passa o país. Ainda assim, apesar da abertura do catálogo, é possível identificar diversos dispositivos constitucionais que apontam para a proteção e a efetivação de um direito fundamental à comunicação.

Como se verifica, em geral, na doutrina a respeito dos direitos fundamentais, há divergências em relação à melhor classificação a ser adotada e ao caráter dos diversos direitos - liberdade, prestação e participação. Buscou-se fazer uma leitura integrativa, a partir da qual se tornasse possível qualificar o direito à comunicação como um direito Revista de Direito, Estado e Telecomunicações, v. 3, n. 1, p. 205-280 (2011) 
trivalente, que reúne elementos de direitos fundamentais de liberdade, prestação e participação.

Essa caracterização torna-se sobremaneira valorosa quando se compreende a noção de sociedade em rede, realidade inafastável da era informacional, marcada pela conexão entre os diversos pontos de um determinado conjunto social, presentes em quaisquer localidades do planeta.

É que a sociedade em rede demanda, inquestionavelmente, a ampliação e a concretização de um direito à comunicação de mão dupla, na linha do que preconiza o Relatório MacBride (UNESCO,1980), a partir do qual os indivíduos podem emitir e receber informações, produzindo suas próprias manifestações e divulgando-as livremente, sejam elas quais forem.

Para além dessa exigência, a sociedade em rede requer ainda condutas positivas do Estado, que deve oferecer aos cidadãos a possibilidade de se inserirem no contexto de conexão, sob pena de serem privados de diversos outros direitos fundamentais cujas concretizações, no mundo atual, dependem - e dependerão cada vez mais - do acesso às tecnologias da informação.

A internet ganha realce dentro de tais circunstâncias, uma vez que constitui verdadeira revolução na comunicação e na própria estrutura social, alterando o modelo de relacionamentos interpessoais e de produção na economia informacional. Trata-se da ferramenta tecnológica básica e fundamental para a inclusão de qualquer pessoa na nova realidade global.

Desse modo, torna-se primordial a preocupação acerca da garantia do acesso à internet, além de se assegurar uma largura de banda suficiente para a utilização dos instrumentos nela disponibilizados, bem como da capacitação específica dos indivíduos, aplicada à realidade na qual se inserem, a fim de que os novos recursos sejam-lhes úteis e capazes de melhorar as condições de vida daquela população.

Nessa mesma linha, ressalte-se a importância de o Brasil desenvolver, ao lado das políticas públicas que visam à ampliação das redes, ou seja, da infraestrutura necessária à garantia do acesso massificado, outros programas que tenham por finalidade a verdadeira inclusão digital das pessoas, que ultrapassa o mero acesso e depende também da qualificação específica para manusear as ferramentas tecnológicas importantes para o seu contexto social. 
Conclui-se que há, hoje, no Brasil, instrumentos legais e constitucionais suficientes para se reconhecer o caráter fundamental do direito à comunicação no ordenamento jurídico nacional. Há ainda que se destacar as recentes iniciativas governamentais no sentido de ampliar o acesso à internet de alta velocidade, realizado na medida do possível, consideradas as dificuldades naturais de um país de grandes dimensões e de diversidade cultural e econômica.

O fato, porém, que se constata com mais clareza é que essas iniciativas devem se manter sempre vinculadas à percepção de que a sociedade em rede, na qual o Brasil ainda não se encontra plenamente inserido, é um parâmetro fundamental, sendo imprescindível avançar até uma situação de desenvolvimento, em todas as áreas, que passa pela utilização dos recursos e das ferramentas relacionados à internet. Veja-se a posição de Castells nesse sentido:

A divisão digital fundamental não é medida pelo número de conexões com a internet, mas pelas consequências tanto da conexão quanto da falta de conexão. Porque a internet (...) não é apenas uma tecnologia. É a ferramenta tecnológica e a forma organizacional que distribui informação, poder, geração de conhecimento e capacidade de interconexão em todas as esferas de atividade. (...) Por um lado, estar desconectado ou superficialmente conectado com a internet equivale a estar à margem do sistema global, interconectado. Desenvolvimento sem a internet seria 0 equivalente a industrialização sem eletricidade na Era Industrial. É por isso que a declaração frequentemente ouvida sobre a necessidade de se começar com os 'problemas reais do Terceiro Mundo' - designando com isso saúde, educação, água, eletricidade e assim por diante - antes de chegar à internet, revela uma profunda incompreensão das questões atuais relativas ao desenvolvimento. Porque, sem uma economia e um sistema de administração baseados na internet, qualquer país tem poucas chances de gerar os recursos necessários para cobrir suas necessidades de desenvolvimento, num terreno sustentável - sustentável em termos econômicos, sociais e ambientais. ${ }^{120}$

${ }^{120}$ CASTELLS, Manuel. A Galáxia da Internet: reflexões sobre a Internet, os negócios e a sociedade. Trad. Maria Luiza X. de A. Borges. Rio de Janeiro: Jorge Zahar, 2003. p. 220.

Revista de Direito, Estado e Telecomunicações, v. 3, n. 1, p. 205-280 (2011)

DOI: https://doi.org/10.26512/1str.v3i1.21671 
Assim, a despeito de ser um país em desenvolvimento, com grandes desafios a serem superados em diversas áreas, consideradas geralmente mais básicas ou fundamentais para a superação da pobreza e da desigualdade, é indispensável que o Brasil invista na formação de um modelo econômico e administrativo baseado na internet, o que repercute nas esferas individual e social, a fim de que se possibilite o desenvolvimento nacional em todos os níveis.

De fato, pode-se afirmar que “(...) a internet é mais do que simplesmente uma forma diversa de acessar ou distribuir informações e bens culturais, (...) é uma plataforma para novas maneiras de produzi-los." ${ }^{121} \mathrm{Na}$ verdade, a internet reestrutura a lógica da sociedade atual. Daí seu valor e a urgência de se atentar para as possibilidades que dela defluem, para que se alcance um estágio de real concretização do pleno direito fundamental à comunicação, cujo espectro é muito mais abrangente do que o mero acesso à informação.

\section{Bibliografia}

AKWULE, Raymond. Global Telecommunications: the Technology, Administration, and Policies. Boston: Focal Press, 1992.

ALCALÁ, Humberto Nogueira. El derecho a la información en el ámbito del derecho constitucional comparado en Iberoamérica y Estados Unidos. In: Ius et Praxis 6(1): 321-404, 2000.

ALEXY, Robert. Teoria dos Direitos Fundamentais. Trad. Virgílio Afonso da Silva. São Paulo: Malheiros, 2008.

ARANHA, Márcio Iório (org.). Coletânea de Normas e Julgados de Telecomunicações e Glossário Brasileiro de Direito das Telecomunicações. São Paulo: Quartier Latin, 2006.

\section{Políticas públicas comparadas de telecomunicações (Brasil-}

EUA). Tese de doutorado. Centro de Pesquisa e Pós-Graduação sobre as Américas. Universidade de Brasília, 2005.

ARONSON, Jonathan D.; COWHEY, Peter F.; with ABELSON, Donald. Transforming global information and communication markets: the

${ }^{121}$ FARACO, Alexandre Ditzel. Democracia e regulação das redes eletrônicas de comunicação: rádio, televisão e internet. Belo Horizonte: Editora Fórum, 2009. p. 269. 
political economy of innovation. Cambridge and London: The MIT Press, 2009.

BAR, François; SANDVIG, Christian. US communication policy after convergence. In: Media, Culture \& Society. Los Angeles: SAGE Publications, 2008.

BENKLER, Yochai. The Wealth of Networks: How Social Production Transforms Markets and Freedom. New Haven and London: Yale University Press, 2006.

Open-source economics: Yochai Benkler on TED.com. Palestra proferida em Oxford, Inglaterra, em julho de 2005. Vídeo disponível em http://blog.ted.com/2008/04/yochai_benkler_1.php (acesso em $07 \mathrm{de}$ agosto de 2009).

BRASIL. Ministério das Comunicações. Diretrizes gerais para a abertura do mercado de telecomunicações: sumário executivo. Disponível em: http://www.anatel.gov.br/Portal/exibirPortalInternet.do\#. Acesso em $30 \mathrm{de}$ outubro de 2009.

CANOTILHO, José Joaquim Gomes. Estudos sobre direitos fundamentais. $1^{a}$ Ed. Brasileira. São Paulo: Ed. Revista dos Tribunais, 2008.

CARDOSO, Gustavo. Sociedades em transição para a sociedade em rede. In: CARDOSO, Gustavo; CASTELLS, Manuel (org.). A sociedade em rede: do conhecimento à acção política. Lisboa: Imprensa Nacional, 2005. p. 31-64.

CARVALHAES NETO, Eduardo Hayden. Noções de universalização de serviços de telecomunicações no Brasil. In: Revista de Direito de Informática e Telecomunicações 4: 81-113, 2008.

CASTELLS, Manuel. A Galáxia da Internet: reflexões sobre a Internet, os negócios e a sociedade. Trad. Maria Luiza X. de A. Borges. Rio de Janeiro: Jorge Zahar, 2003.

A sociedade em rede. A era da informação: economia, sociedade e cultura. Vol. 1. Trad. Roneide Venâncio Majer. São Paulo: Paz e Terra, 1999.

A sociedade em rede: do conhecimento à política. In: CARDOSO, Gustavo; CASTELLS, Manuel (org.). A sociedade em rede: do 
conhecimento à acção política. Lisboa: Imprensa Nacional, 2005. p. 1730 .

DUARTE, Denianne de Araújo; SILVA, Lívia Denise Rêgo. Backhaul ameaçado, consumidor atento. In: Revista de Direito, Estado e Telecomunicações (RDET) 1(1): 210-232 (2009).

FARACO, Alexandre Ditzel. Democracia e regulação das redes eletrônicas de comunicação: rádio, televisão e internet. Belo Horizonte: Editora Fórum, 2009.

GALPERIN, Hernan; MARISCAL, Judith (org.). Digital Poverty: Latin American and Caribbean Perspectives. Practical Action Publishing/ IDRC, 2007.

GOMES, Daniel Augusto Vila-Nova. A noção de serviços públicos de (tele) comunicações a partir da ótica dos administradosadministradores: a Lei $n^{0}$ 9.612/1998 e contribuições da cidadania nas políticas públicas destinadas às rádios comunitárias. Dissertação de Mestrado. Faculdade de Direito. Universidade de Brasília, 2007.

HÄBERLE, Peter. Estado constitucional cooperativo. Trad. Marcos Augusto Maliska e Elisete Antoniuk. Rio de Janeiro: Renovar, 2007.

HESSE, Konrad. A força normativa da Constituição. Trad. Gilmar Ferreira Mendes. Porto Alegre: Sergio Antonio Fabris Editor, 1991.

Concepto y cualidad de la Constitución. In: Escritos de Derecho

Constitucional. Madrid: Centro de Estudios Constitucionales, 1983.

HUDSON, Heather E. Maximizing Benefits from New Telecommunications

Technologies: Policy Challenges for Developing Countries. In: JUSSAWALlA, Meheroo (org.). Global Telecommunications Policies: The Challenge of Change. Wesport: Greenwood Press, 1993.

JUSSAWALA, Meheroo. Challenge of Change. In: JUSSAWALLA, Meheroo (org.). Global telecommunications policies: the challenge of change. Wesport: Greenwood Press, 1993.

KELSEN, Hans. Jurisdição Constitucional. São Paulo: Martins Fontes, 2003.

LAENDER, Gabriel Boavista. A Separação de Poderes e o Processo de Institucionalização das Agências Reguladoras de Telecomunicação nos EUA e no Brasil. Dissertação de Mestrado. Faculdade de Direito. Universidade de Brasília, 2009. 
LASSALLE, Ferdinand. O que é uma constituição? Trad. Walter Stönner. Porto Alegre: Editorial Villa Martha, 1980.

LOEWESTEIN, Karl. Teoría de la Constitución. Trad. Alfredo Gallego Anabitarte. $2^{\text {a }}$ ed. Barcelona: Editorial Ariel, 1986.

LOPEZ-AYLLÓN, Sergio. El derecho a la información como derecho fundamental. In: Derecho a la información y derechos humanos. CARPIZO, Jorge; CARBONELL, Miguel (org.). Ciudad del México: Universidad Nacional Autónoma de México, 2000.

MELLO, Celso Antônio Bandeira de. Curso de direito administrativo. 21 ${ }^{\text {a }}$ ed. São Paulo: Malheiros, 2006.

MENDES, Gilmar Ferreira [et al.]. Curso de direito constitucional. São Paulo: Saraiva, 2007.

RIPPER, Mário Dias. Universalização do acesso aos serviços de telecomunicações: desafios atuais no Brasil. Disponível em: http://www.ie.ufrj.br/desenvolvimento/pdfs/universalizacao_do_acesso_ao s_servicos de telecomunicacoes.pdf. Acesso em 30 de outubro de 2009.

SARLET, Ingo Wolfgang. A eficácia dos direitos fundamentais. $9^{a}$ Ed. Porto Alegre: Livraria do Advogado, 2007.

(org.). Direitos fundamentais, informática e comunicação:

algumas aproximações. Porto Alegre: Livraria do Advogado, 2007.

SILVA, Virgílio Afonso da. A constitucionalização do direito: os direitos fundamentais nas relações entre particulares. São Paulo: Malheiros, 2008.

SUNDFELD, Carlos Ari. Fundamentos de direito público. $4^{\text {a }}$ Ed. São Paulo: Malheiros, 2005.

TRINDADE, Antônio Augusto Cançado. Desafios e conquistas do Direito Internacional dos Direitos Humanos no início do Século XXI. In: Desafios do Direito Internacional Contemporâneo. Jornadas de Direito Internacional Público no Itamaraty. Antônio Paulo Cachapuz de Medeiros (org.). Brasília: Fundação Alexandre de Gusmão, 2007.

UNESCO. Many Voices One World. London: Kogan Page, 1980. Disponível em http://unesdoc.unesco.org (acesso em 23 de setembro de 2009).

UNIÃO INTERNACIONAL DE TELECOMUNICAÇÕES. ITU Digital Access Index: World's First Global ICT Ranking Education and 
Affordability Key to Boosting New Technology Adoption. Disponível em http://www.itu.int/newsroom/press_releases/2003/30.html (acesso em 07 de agosto de 2009).

VEDANA, Vilson. Uma política pública para inclusão digital. In: Revista de Direito de Informática e Telecomunicações 3(4): 207-228 (2008).

WIMMER, Miriam. O direito à comunicação na Constituição de 1988: o que existe e o que falta concretizar. In: Eco-Pós (UFRJ) 11: 146-165 (2008). 
